\title{
The French staff material from Johann Georg Pasch
}

\author{
Olivier Dupuis, \\ independent researcher, \\ dupuisolivier@yahoo.fr
}

\begin{abstract}
Johann Georg Pasch was a very prolific author who published a large number of books during the third quarter of the seventeenth century. Some of these included physical exercises with a long staff and presented by Pasch himself as coming from France. Among all the known editions, four different versions can be isolated; this offers the possibility to study the filiation of the edition process. This study is combined with a textual criticism of the material, beginning with a comprehensive biography from the author and finishing with the questioning of the French origin.
\end{abstract}

Keywords - critical edition, staff, Johann Georg Pasch

\section{INTRODUCTION}

The main goal of this article is to propose a critical edition of the long staff material from Johann Georg Pasch, coupled with a history of publication and the filiation of editions. The growing interest in this subject over the last few years is demonstrated notably by three distinct translations in English. ${ }^{1}$ There are also other purposes, since this critical edition is not just a mere transcription: it has to stay faithful to the German type of scholarly edition, to analyze the text's origin and provenance. ${ }^{2}$ This paper will thus present first a contextualization of the text, including biographical information and then a description of the content.

\section{CONTEXTUALIZATION}

\section{II.1. The life of Pasch $(1628-1678)$}

\section{II.1.1. From birth to death}

First, I must justify the use of the spelling Pasch. Johann Georg Pasch himself used the spelling Paschen in genitive tense and Pascha in other cases. In his French translations, he

\footnotetext{
* I am indebted to Jean Chandler for his help in translating the manuscript, as well as the anonymous peer-reviewer who provided copy-editing.

1 Van Noort in 2014 with Pascha's Hunting Staff and in 2015 with Pascha's Staff with Two Ends, Crawley in 2013 with The Polearm Compendium.

${ }^{2}$ For an introduction to textual criticism and the differences between English and German tradition in that matter, see Gabler, Textual Criticism.
} 
also used Pasche. The German libraries catalogs often used the modern German form Pasch as did also Schlöttermüller in his edition of the dance treatise. ${ }^{3}$ The choice for this article was to use the modern form of this name instead of the historical spelling for the sake of clarity and consistency.

Despite there being a huge number of books published under his name, very little information about Johann Georg Pasch is available, except for what can be found in his own words, as recently pointed out by Wellmann. ${ }^{4}$

Fortunately, a valuable source of information about the life of Pasch has been found some time ago: a long sermon written and printed for his funeral, printed as was the custom at the time. ${ }^{5}$ Some of the information from this document has not been confirmed and should be handled with caution. It states that Johann Georg was born on September $9^{\text {th }}$ 1628 in Dresden. His mother, Magdalena Frauenstein was the daughter of Georg Frauenstein, a businessman and member of the city council of Dresden. His father, Johann Pasch, was a servant at the court of the Prince of Saxony and his grandfather, Joachim Pasch, first minister of the protestant church of Zittau. The sermon does not give any information about his siblings, but he was possibly one of the younger children as his parents preferred him to begin work early. Pasch, who certainly received a good education, preferred instead to continue his studies in Zittau, Berlin and finally in the Marienstift Gymnasium of Stettin, in the Pomerania, where he received a classical education in Latin. ${ }^{6}$ The student registers stored in the city's archives are only available from 1793 onwards. Therefore it is difficult to estimate how long he stayed at this school, but it was probably until between 1643 and 1645 .

The sermon further ascertains that Hugh Hamilton recruited Pasch directly from the school to serve as private tutor for his children in the city of Gdańsk, but also that Pasch went to Greifswald, and then Rostock, after staying in Gdańsk, without giving any accurate dates. Hamilton was an Irish colonel, serving in the Scottish armies of the Swedish Empire of Sweden, which at that time, controlled most of the Pomerania. Hamilton was named commander of the regiment in Riga in 1641 and took position at Greifswald in 1645.7 It is very likely that Pasch entered Hamilton's service of Hamilton before he was recorded in Greifswald, but probably not long before that, because Pasch was only eighteen years old at the time. The funeral sermon also states that Pasch pursued his studies in both cities, Greifswald and Rostock, which each had a well-established

\footnotetext{
3 Pasch, Anleitung..., pp. 12-21.

4 Wellmann, Katalog, p. 253.

${ }^{5} \mathrm{I}$ am indebted to Jan Schäfer who found this sermon. It is partially published by Hazebroucq, $L a$ technique de la danse, pp. 124-27. For more information about funeral sermons in Germany, see Bibza, Die deutschsprachige Leichenpredigt, pp. 21-24.

6 Wehrmann, Geschichte des Königlichen Marienstifts-Gymnasiums, pp. 49-73.

7 Murdoch and Grosjean, Alexander Leslie, pp. 151 and 162.
} 
university. ${ }^{8}$ He studied physical exercises such as fencing, wrestling, flag waving, and also playing the lute. It is very tempting to imagine these military studies were carried out with the help and influence of the colonel Hamilton, or at least in one of the regiments he was in charge of. Pasch informed us that his military knowledge about maneuvers with muskets came from an experienced officer, which is possibly a reference to Hamilton: Lieber Leser, nach dem ich das sehr nützliche Exercitium mit der Mußquet von einem Exercitio erharnen Officirer erlernet. ${ }^{9}$

The sermon informs us that in 1649, Pasch went back to his homeland, but stayed there only briefly before going to the University of Wittenberg in 1650, where he produced and published two legal dissertations in 1652 and $1655 .{ }^{10}$ Anecdotally, the second dissertation is a juridical analysis of the famous kidnapping of the two sons from the prince Frederick II by Kunz von Kaufungen in $1455 .{ }^{11}$ The sermon also states that Pasch already gave lessons in physical and rhetorical exercises, both establishing him as a local celebrity among students, professors and also the young aristocracy. In 1656, he was installed as archivist of Duke Augustus, administrator of the Archbishopric of Magdeburg. The administrator was in fact a secular prince who acted as the archbishop in the Protestant province. Augustus was therefore Prince-elector of the Holy Roman Empire and the station of archivist was certainly a good opportunity for Pasch's career. ${ }^{12}$ At this stage, Pasch was the perfect illustration of a new class of educated men coming from the burghers and serving the aristocracy as noted by Brunt. ${ }^{13}$

The following year, on November 16, Pasch married Anna Margaretta Siegler, daughter of the burgomeister of Wittenberg. This is confirmed by a small printed collection of the poems and songs played during the feast. ${ }^{14}$ The couple had four children together, Anna Margaretha, born on 03/02/1659, Ehrenfried Christian, born on 05/06/1661, Anna Catharina, born on 18/03/1663 and Augustus, born on 10/01/1666 but surviving only one month. ${ }^{15}$

At an unknown date, Pasch became the secretary of the chancellor of Thuringia, probably after Augustus inherited the title of Duke of Saxe-Weissenfels. Finally, in 1662, he was appointed Pagenhofmeister at a page school located in Halle (Saale). I have not been able

${ }^{8}$ Guntau, Die frühen norddeutschen Universitätsgründungen Rostock, und Greifswald.

${ }^{9}$ Deutliche Beschreibung von dem Exerciren in der Musquet und Pique, before the last page of the musket section, the second page that received the number 35.

10 Dissertatio Politica de Legato Dissertatio in 1652 and De Plagio Kaufungiano in 1655.

11 This subject of historical study is still fashionable. See in particular Der Altenburger Prinzenraub 1455. I am also indebted to Bert Gevaert for the analysis of the Latin text.

12 For more information about August, see Allgemeine Deutsche Biographie, 1, pp. 680-81.

13 Brunt, The Influence of the French Language, pp. 83-84.

14 Festivitati Nuptiali Viri Clarissimi et Consultissimi Dni. Johannis Georgii Paschn.

$15 \mathrm{It}$ is worth mentioning that the birth dates of the children did not appear in the funeral sermon for Johann Georg, but did appear in the funeral sermon for his wife. See Christoph Schrader, Die treue Gebülffin, p. 7. 
to find any description for this post. In his bilingual treatise of 1673, Pasch translated it into French as Gouverneur des pages. This position could have been created due to the influence of the French court, ${ }^{16}$ but this has yet to be confirmed. However, if it is true, this post had nothing to do with sport and military training. The governor of the pages is the manager for the pages' institutions. At the French court, the pages were young boys coming from noble families who had the opportunity to serve at the court for a year or more. They also received some kind of education. The governor of the pages was responsible for the entire range of the pages' service. ${ }^{17}$

In 1674, Pasch was involved in a project for founding a new Academy for the young aristocracy of the court of Saxony, probably following the model of different Ritterakademien that flourished in Germany during the mid-seventeenth century. ${ }^{18}$ Moreover, in 1675 he received a salary of 100 thalers from the Oberlausitz court for an unspecified role. However, the archive mentions him as churfürstlich sächsischen Cämmerirer which means member of the court of the Prince of Saxony. ${ }^{19}$

According to her funeral sermon, Pasch's wife became sick and died on August 23 1678. ${ }^{20}$ Pasch himself had fallen ill during the summer and had to stay home because of tremors. His funeral sermon suggested a link between these tremors and a blow he received on the left side of the head. However, this is far from certain, especially since this sermon did not even mention the disease of his wife. A contagious disease is a far more likely candidate for explaining his death than a blow received two months before. Eventually, Johann Georg Pasch died 49 years old, on September 1st, 1678.

\footnotetext{
16 Brunt reports that the court of Versailles was the ideal for the German aristocracy, who imitated in architecture, dress and way of life. Read in particular pp. 3-4 and pp. 27-28.

${ }^{17}$ For example Philibert Morin, sieur de La Touche, a French fencing master, held two positions at the queen's court in 1677: fencing master and governor of pages. He received 200 pounds a year for the first post and 300 for the second. See L'État de la France, p. 395.

18 For a quick overview, see Brunt, The Influence of the French Language, pp. 73-75.

19 See Müller, Ein Versuch zur Gründung einer Ritterakademie, pp. 47-48.

20 Christoph Schrader, Die treue Gebülffin, p. 8.
} 


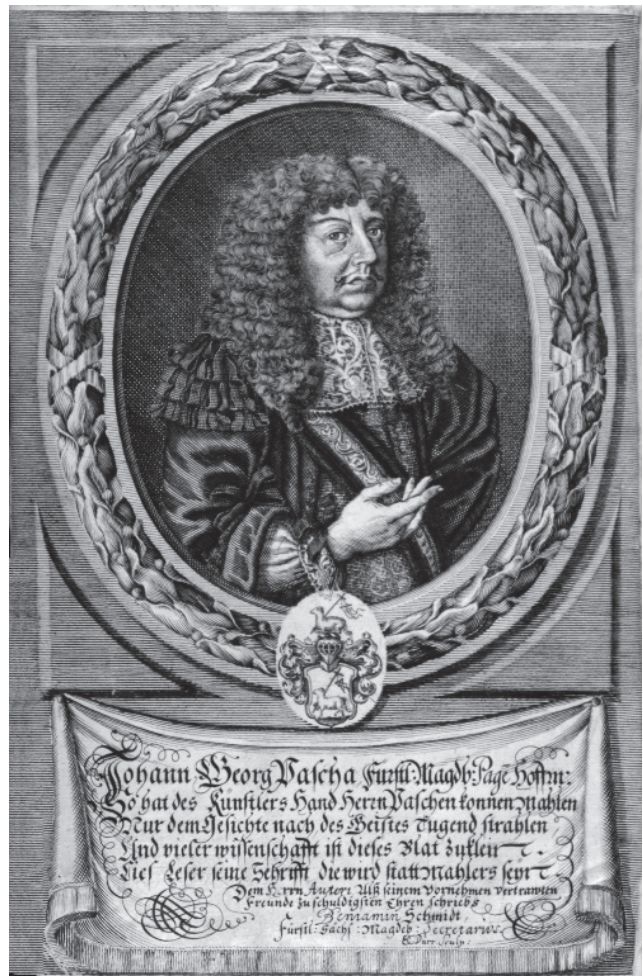

Figure 1: portrait of Pasch in 1673.

Pasch, Deutliche Beschreibung unterschiedener Fabnen-Lectionen, p. 2. Herzog August Bibliothek. Wolfenbüttel: Xb 4 157.

\section{II.1.2. Pasch, the author}

Each phase of the life of Pasch seems linked by printed books. His first contact with the literary world was the publication of two legal dissertations in 1652 and 1655 at the University of Wittenberg. ${ }^{21}$ His second was the publication of his wedding's songbook. ${ }^{22}$ He then produced an astonishing number of publications and re-publications between 1657 and 1673. Indeed Pasch was one of the most prolific authors on the subjects of body movements and physical exercises of that period. The number of subjects he addressed was impressive: partisan, flag waving, vaulting on horses or tables, wrestling, fencing with on the thrust and on the cut, and the long staff. He also produced books about dancing, military maneuvers with muskets and pikes, and even about the art of fortification. His books are either compilations of the subjects listed above, or monographs. And, as will be demonstrated through his work on the long staff, each

\footnotetext{
21 Dissertation Politica de Legato and Dissertatio de Plagio Kaufungiano.

22 Festivitati Nuptiali Viri Clarissimi et Consultissimi Dni. Johannis Georgii Paschn.
} 
subject was continuously refined or simply evolved with each edition, in such way that a comprehensive bibliography from his entire works with classification of each content goes largely outside the scope of this paper.

It is difficult to tell which parts of his work are his own work or which are copied, translated or adapted from other works. For example, Krebs suggested that his art of carving and serving the meat is an abbreviated form of an older German book about the same subject. ${ }^{23}$ On the other hand, Hazebroucq explained that his material about the art of dancing is unique and important in the history of that art, in particular as it is the only source giving technical details about French dances from the mid-seventeenth century. ${ }^{24}$

What could have been the motivations of Pasch to write so many books? In his first book, published in 1657 when he had just become archivist, he explained his reasons for producing it. He claimed that after a certain time spent studying and also teaching physical exercises (Exercitia corporis) to groups of people, good friends suggested that he publish these exercises. Such entourage certainly helped him in time where it was very difficult to publish in Germany without any patronage..$^{25}$

However, it is conceivable that the production of the following books, especially between 1659 and 1661 helped him to get the job of governor of the pages in Halle. He also may have received special commissions from different patrons, which could explain why many of his books are dedicated to different people. As an example, Müller mentions a document proving that Pasch had received twenty thalers for the dedication of a book in $1670 .{ }^{26}$ Nevertheless, unlike La Touche who addressed his book to the king of France expecting to receive the post of fencing master of the Dauphin, ${ }^{27}$ Pasch did not dedicate any books directly to Prince August before 1670. Finally, as mentioned before, even his funeral sermon was printed.

\section{II.2. Editions on the long staff or baston à deux bouts}

\section{II.2.1. The first version $A$ and its partial edition $a^{\prime}$}

The first document from Pasch that mentioned the staff was his book entitled "Brief information about the pike, flag, partisan, hunting staff, vaulting, wrestling, fencing with thrust and cut, and finally how to carve and serve meat" (Kurtze Unterrichtung Belangend Die Pique, die Fabne, den Jägerstock, das Voltegiren, das Ringen, das Fechten auff den Stoß und Hieb und endlich das Trinciren). It was published for the first time in 1657 and received two re-editions under the same title in 1658 and 1659, which were printed by the same printer, Ölschlegel in Wittenberg, and distributed by the same book-seller, Christian Guths from Hamburg.

\footnotetext{
${ }^{23}$ Krebs, Quand les allemands apprenaient à trancher, p. 15.

${ }^{24}$ Hazeboucq, La technique de la danse, p. 11-21 and 115.

25 Brunt, The Influence of the French Language, pp. 82-84.

26 Müller, Ein Versuch zur Gründung einer Ritterakademie, p. 48 footnote 19.

${ }^{27}$ Lahaye, Le fils de Louis XIV, pp. 50-52.
} 
I have only been able to consult the more recent edition but since all mentioned details are identical I am inclined to think that the text was likewise identical. Indeed, this last edition still contained the introduction dated from February $9^{\text {th }}$ 1657. The same year, in 1659, Pasch published another book on various subjects including some from this first one. It is unlikely that Pasch would have taken time to modify an old version while working on his new book.

As noted previously, Pasch explained in the introduction of this book that he produced it for his friends and his students. He certainly worked on the printed edition before being recruited as archivist, as on the title page he stated that he was a law student (LL.Studiosus). ${ }^{28}$ However, it is worth noting that he also explained clearly that teaching such exercises was not his main profession: In Betrachtung die Exercitia niemals meine Profession gewesen.

This first book of 132 pages contains a long selection of different subjects. The works with the pike, wrestling and the serving art all received developed and detailed sections, while the section on the hunting staff or partisan (Jägerstock oder partisan) is limited to the titles of the different lessons. The other sections dedicated to fencing, flag waving and vaulting received an intermediate treatment: they each had an introduction followed by the titles of the lessons.

This list of lessons, included as an appendix to this article, closely follows the program developed in the later publications, and even contains some lessons left out of the later works. However, this proves that Pasch had already organized a large part of what would be published and developed in subsequent books. This also provides further evidence to suggest that Pasch already had a written version for the lessons, even if he did not publish it in this first book.

For that reason, I believe that at least one original edition existed, probably a manuscript version of the staff material from Pasch, unknown to us, that by convention receives the siglum $A$. The partial edition in 1657 is then limited to the title of each section and will be referenced later with the siglum $a$.

\section{II.2.2. Variant $b$, first complete edition}

In 1659 Pasch published a second compilation of different materials under the long title: "Short but thorough briefing on the pike, drilling with the pike, the flag, the hunting staff, serving art, fencing on the thrust and the cut, vaulting on horses and on tables, wrestling, and dancing" (Kurtze doch Gründliche Unterrichtung der Pique, deß Trillens in der Pique, der Fabne, deß Jägerstocks, Trincierens, Fechtens auf den Stoß und auf den Hieb, Voltesirens auf den Pferd und auf den Tisch, deß Ringens, Tantzens). Curiously, the bookseller and printer, Johann Georg Schwander, signed the introduction of the book, rather than its author. He dedicated the entire book to the Senate of Osnabruck after having been granted citizenship to this Free

28 "LL.studiosus" was a common way to designate a student in law at that time. See Pasch, Anleitung, p. 28 footnote 15. 
City. This book was certainly a commission made by this bookseller himself to Pasch, which could explain why only the initials of the author, IGP, appeared on the title page. ${ }^{29}$

The section on the hunting staff (Jägerstock) appears on folios 74 recto to 82 verso. The text is composed with an introduction of seven paragraphs followed by twenty-two lessons. This edition does not reproduce six lessons that are listed in $a$ '. There is only one illustration at the beginning of the section, which is reproduced below. One should also note the presence of a staff with two points on the engraving at the beginning of the book. The engraver who produced these pictures signed his work by the monogram JHB but remains unknown at this date.

An interesting detail of the writing process of this text can be found in lessons 3, 6 and 16 of this edition. There, Pasch told us that he must himself at each time turn to the left: muß ich mich iederzeit lincks berum kehren. This is the only time that the first-person pronoun is used in Pasch's work on the staff. The first two of these lessons were modified in the next version, and the last in the $e$ version. This could be seen as a proof that a previous version of the text existed which was written in the first-person. Pasch probably decided to modify all the pronouns to the third-person for the printed edition of the text.

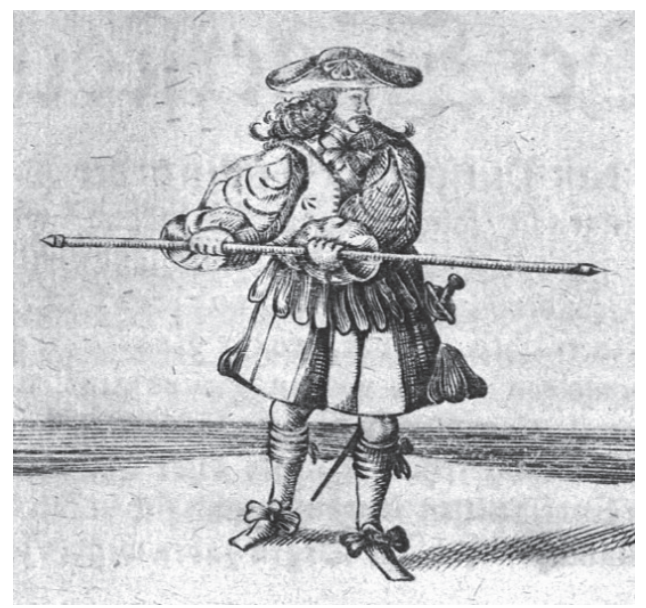

Figure 2: Fighter with a bunting staff or Jägerstock. Pasch, Kurtze Unterrichtung Belangend die Pique, die Fabne, den Jägerstock, p. 156. Württembergische Landesbibliothek, Stuttgart:

Sport.oct.357.

\section{II.2.3. Variant $c$, second complete edition}

In 1660, Johann George Pasch produced a small monograph called "Short introduction to the hunting staff or half-pike" (Kurtze Anleitung des Jäger Stocks oder Halbe Pique). It was printed in Halle (Saale) by Melchior Ölschlegel, and published by Johann Enst Tietze without any dedication. Hence, it is difficult to know the context that justifies the publication of such a

${ }^{29}$ Pasch, Anleitung, pp. 8-12. 
small book. The only exemplar consulted was bound with other books from Pasch printed the same year. It is actually the third document inside the book 8 ARS MIL 1106/3 from the State University Library of Lower Saxony of Goettingen. However, unlike the previous compilation, each document here is autonomous, which means that each has its own complete title page with edition date. It is thus not possible to determine whether it was distributed alone, or inside a larger compilation.

The most obvious improvement from the previous edition was the addition of a set of sixteen illustrations, with direct references to these inside the text. However, Pasch also proceeded to make minor modifications of the text, and combined the last two lessons into one. This version thus contained only 21 lessons.

\section{II.2.4. Variant $e$, third complete edition and the hypothetical variant $d$}

In 1666 Pasch published a new compilation of different works entitled "Complete Fencing, Wrestling and Vaulting Book" (Vollständiges Fecht- Ringe und Voltigier Buch) with Christian Vester, in Halle (Saale). Naturally, it contains material about fencing with rapier, wrestling, and vaulting, but it also contains a complete chapter about the staff. Each part has its independent title, and the one for the staff is "Short Instruction about Baston à deux bous, Hunting staff or half-pike or Jumping-staff” (Kurtze Anleitung, Wie der Baston à Deux Bous, Jägerstock oder halbe Pique oder Springestock). This book is dedicated to the Silesian principality of Oels. ${ }^{30}$ This was a completely new version of the staff material, including thirteen new lessons, and a completely new set of illustrations.

Pasch re-used this last version of his staff material almost identically in two other editions. The first was another compilation entitled "Clear description of the exercises in Musket and Pike and also about the baston à deux bous or hunting staff' (Deutliche Beschreibung von dem Exerciren in der Musquet und Pique, wie auch von dem Baston a deux Bous, Jägerstock). This was printed in 1667, again by Christian Vester, re-using the same plates for the illustrations and the typographic pages for the staff, except for the dedication page. This time, it was dedicated to a certain Frederick, Duke of Saxony. Pasch probably anticipated a little bit as Frederick $1^{\text {st }}$ was only made Duke of Saxe-Gotha-Altenburg officially in $1675 . .^{31}$

The third re-edition appeared with the title "Short instructions how the Baston à deux bouts, that is Hunting staff, Half Pike or Leaping Pole is actually to be used" (Kurtze Anlejdung wie der Baston à deux bous das ist Jaegerstock, halbe Pique oder Springe-Stock eigentlich zu gebrauchen). The title page informs us that this book was printed by Friedrich Arnst in Leipzig in 1670. Below, a complement of text informs us that this work was supposed to have been "mostly translated to German, with diligence, from the French language" (Mit Fleiß meistentheils aus französicher Sprache tentsch übersetzt). Curiously, the book contains a second and somewhat different title page. This page presents a slightly different title: "Short instructions how the Baston à deux bouts, the Hunting staff, Half Pike or Leaping

${ }^{30}$ For more information about this principality, see Köbler, Historisches Lexikon, p. 490.

31 Allgemeine Deutsche Biographie, 8, pp. 2-3. 
Pole as it is called by many, is actually to be used" (Kurtže Anleitung wie der Baston à deux bous, Jägerstock, oder halbe Pique oder Springestock wie ibn etliche nennen, eigentlich zugebrauchen), and on which Furthermore, here the printer's name is given as Christian Vester, working in Halle, as for the two previous editions, and the printing date was 1669. It should also be noted that any mention of a translation from French to German is missing. All the following pages, after the dedication pages, are identical to the two previous editions mentioned in this section. I was not able to find an independent version of the 1669 edition. Therefore, I suppose that the printing was carried out by Christian Vester, but that, for an unknown reason, the prints were not distributed, until, in 1670, Pasch re-used the printed books and asked Arnst, printer from Leipzig, to produce a new title page, and maybe the dedication section, and to perform the binding of the books. Finally, it is worth noting that this edition was dedicated directly to Augustus, administrator of Magdeburg. Compared to the previous known versions, $b$ and $c$, this version $e$ adds thirteen lessons. Most of these additions are not essential to the art, and consist of variations on the existing exercises. For example, lesson 19, as added in version $e$, instructs the reader to "perform [the previous] lesson with two strikes in all four directions". ${ }^{32}$ The only exception is lesson 31, in which Pasch introduced a new exercise, the jumping thrust. This version was also the first one to give the French name baston à deux bouts, meaning "staff with two ends", to the material, before the German name jägerstock or "hunting staff".

One great improvement was the addition of a completely new set of 33 illustrations. These illustrations were certainly produced by Johann Georg Flach, an engraver who was in business with Pasch since at least 1661, in which year Flach put his monogram in the form of his initials, "JGF made it" (JGF Fecit) above the engraving in two books produced by Pasch. The dictionary of monograms of Brulliot confirmed that these initials are Flach's. Brulliot even noticed sarcastically that Flach was a "poor engraver who produced engravings for subjects of little importance". ${ }^{33}$ In the book on the musket which contains a section on the long staff, the engraving on the front page holds the unambiguous text Johann George Flach Inven: et fecit 1667, which proves that Flach was also the artist who created the illustrations and that he did not only engrave them. This relation between Flach and Pasch was certainly strong as Flach was mentioned in the funeral sermon as being at the side of the couple during their sickness.

Finally, in this version, lessons 27 to 29 all made erroneous references to previous chapters ( 20 to 22 instead of 23 to 25 as expected). There is no such mistake in the $b$ and $c$ versions, and the next version, though being shortened, gave the correct reference in the $27^{\text {th }}$ lesson, to the previous 23 lesson. One can immediately set aside the idea of a direct copy of the known previous version as the numbers differed: the references were previously to lessons 15 to 17 . Therefore, here it is possible to see a piece of evidence for the existence of an intermediate version between $c$ and $e$ where three of the new lessons have not yet been

\footnotetext{
32 Translation by Van Noort.

33 Brulliot, Dictionnaire des monogrammes, 1, p. 191, number 1480. The two books are Kurtze jedoch Deutliche Beschreibung handlend von Fechten auß dem Stoss und Hieb and Vier und achtrig Fabnen-Lectiones.
} 
added. Without any known published versions, it should be considered as a manuscript version. I therefore suggest to refer to this hypothetical version with the siglum $D$. If such an edition had existed, its production should be estimated between 1661 and 1665 .

\section{II.2.5. Variant $f$, the bilingual version}

In 1673, Pasch published a huge compilation of different subjects all described in both German and French, printed in Halle (Saale), by Melchior Ölschlegel. The title was "Separate description of the various lessons with the flag divided in eight plays; Followed by lessons with pike, partisan, and half-pike or the staff with two ends" (Description distincte des diverses leçons au drappeau divisées en huit jeux. En suite du jeu de la pique, de la pertuisane et demy pique ou de baston à deux bouts in French and Deutliche Beschreibung unterschiedener FabnenLectionen in acht Spiel eingetheilet, nebst dem Piquen-Spiel, Pertuisan und halben Piquen, oder Jägerstock in German). This version does not contain any dedication.

The etched title page was certainly produced by Johann Georg Flach, even if the monogram differs a little from known examples of his work: the three letters $J, G$ and $F$ are superimposed. Before this title page, a sumptuous portrait of Pasch, etched by another, unknown artist, appears.

In comparison to the previous version, the text for the staff has been shortened in many places, certainly to facilitate the presentation in two columns of both versions, in German and in French. Therefore, this version, despite being the most recent, should not be taken as the ideal version for the edition of the text. However, in some parts of the text it includes some improvements as well as corrections for rare mistakes.

There are three types of differences with the version $e$ :

- removal of paragraphs,

- removal of a large section of the text from the introduction but also from the lessons,

- improvements in the text and corrections of mistakes conserved in previous versions.

\section{II.2.6. Filiation of editions}

The following table summarizes the filiation of editions of the staff material from Pasch. The capital letters refer to handwritten versions, the lower case letters to printed versions.

\begin{tabular}{|c|l|c|}
\hline Variant & \multicolumn{1}{|c|}{ Commentaries and dating } & Set of pictures \\
\hline$A$ & unpublished, existence proved in 1657 & unknown \\
\hline$a^{\prime}$ & partial publication of $A$ in 1657, 1658 and 1659 & no picture \\
\hline$b$ & printed in 1659 & no picture \\
\hline$c$ & printed in 1660 & first set \\
\hline$D$ & hypothetical variant, should have been produced between 1661 and 1665 & unknown \\
\hline$e$ & printed in 1666, 1667, 1669 and 1670 & second set \\
\hline$f$ & printed in 1673 & second set \\
\hline
\end{tabular}

Table 1: Filiation of editions 


\section{II.3. Overview of the content}

\section{II.3.1. Physical description of the staves}

Pasch gives very accurate dimensions for the staff in the second paragraph of the introduction: it should have a thickness of four fingers and a length of three ells and a half: ein starcker Stock obngefehr 4 Finger dicke und viertehalbe Ellen. It is difficult to translate these old measures into modern ones, especially the finger for which there is no modern estimate. Maybe it simply means that the staff is as thick as four fingers aligned? In Germany, the exact length of the ell differed from one city to another between 50 to $80 \mathrm{~cm}$. Pasch was probably aware of the difficulty for a German reader to interpret this size as from the $e$ version he added a more flexible indication "as high as a man can reach", which probably means the height from the ground to the top of the raised hand. Pasch probably used the Saxon ell length, which is about $56.6 \mathrm{~cm} .{ }^{34}$ This gives a $1.98 \mathrm{~m}$ staff, which is coherent with the second indication for a man of $1.60 \mathrm{~m}$ tall. There is one particularity for this weapon that separates it from other pole arms: the two sides have the same thickness and each is provided with the same spear head. Pasch erroneously mentioned a "big extremity" (dicke Ende) in all editions except the last one, where this mention disappeared $(\$ 2)$. This staff is thus a perfectly balanced weapon.

\section{II.3.2. Vocabulary}

Pasch seems to have used a common vocabulary shared between all the physical exercises taught. The most noticeable point is the large borrowing of French words. Brunt studied French influence on the German society in the mid-seventeenth century and the introduction of new fashions coming from France especially in the aristocracy. This influence led to a large production of technical literature, and also explains the extensive use of French vocabulary appearing in Pasch's work. Brunt concludes that from the last third of the seventeenth century, "the use of French words in German was obligatory for any German who wished to demonstrate his learning and superior social status." 35

Some of the French words used by Pasch had already been introduced in German at the end of the sixteenth century or during the first half of the seventeenth century, certainly during the thirty years war: to advance (marchieren), to engage (attaquieren), to defend (defendieren), a manner (Manier), a parry (Parade) or a pike (Pique). The only innovation was a verb to precisely describe to gliding the hands along the shaft (glissiren). According to Brunt's study, Pasch was even the first author to use this word. ${ }^{36}$

\section{II.3.3. Content}

After a short introduction, Pasch proposes a set of exercises or lessons (Lection). The level of detail given is not specific to the staff but looks like the signature style of Pasch. This

\footnotetext{
34 Scholz and Vogelsang, Einheiten, p. 109.

35 Brunt, The Influence of the French Language, pp. 25-28 and 91.

36 Jones, A Lexicon of French Borrowings, pp. 119, 321, 413, 418, 481-82 and 514. Brunt, The Influence of the French Language, p. 321.
} 
set of exercises follow the tradition of the military training of the soldier, ${ }^{37}$ but brought to its highest point, thus leading Pasch to produce a work similar to the analytical methods of the nineteenth century.

Pasch includes many techniques for the student alone with his staff, describing movements without mentioning any target and out of the context of any opponent or opposition, like solo drills. There are also no exercises designed for a group demonstration, as typical for the pike or the flag drill. But they can be used for an individual drill before an audience, in which case Pasch asked to begin and finish the exercises with the salute $(\$ 34)^{38}$.

He presents two types of thrusts, the Spanish-thrust and a thrust done in two times, first to the front and secondly to the back. The Spanish-thrust (\$2-9) is a thrust done while walking and switching hands position after each step. This is certainly derived from the pike exercises. ${ }^{39}$ The thrust done front and back seems more particular to the two pointed staff, thrusting from the two sides alternatively ( $\$ 1$ and 31). The first version mentioned a Spanishthrust done with crossed hands, but this was left out of the later versions.

Pasch proposes a unique type of parry, twirling the staff like a canoe paddle, from below or from above (\$11-12). Pasch also mentioned this parry in version $A$ while turning around but this variant was not conserved in the later versions.

The lateral attacks were divided into two categories, depending on the trajectory of the staff. If the attack follows a near vertical plane, Pasch calls it a strike (Schlag). Otherwise, if the attack follows a near horizontal plane, it is a cut (Hieb).

Pasch proposed two different strikes: in one the hit is charged by passing the point of the staff above the head and switching the hands (\$7-10). The second is done by slipping one hand to another to project the opposite point, either from above, or from below ( $\$ 23-30)$.

There are three different "cuts". One is done with one hand holding the staff by its end and making it rotate. The second is a sort of moulinet done above the head or the shoulder, called a "cut all around" (Hiebe rund herumb) by Pasch. The third is a back and forth cut done from one side to another.

To these actions two salutes are added: one to be done in front of an audience, the other to show your prowess in front of strangers (\$34).

For each lesson, Pasch proposes a specific footwork pattern inside a limited list. Three of these are rotations which are really particular and probably specific to this weapon. The first is a rotation of a quarter turn done with the front foot fixed $(\$ 1, \S 21-22)$. This could be coupled with a two steps forward to attack in such a way that rotation could be done with the same foot and in the same direction $(\$ 2, \S 7, \S 9, \S 23, \S 27)$. The second is a cycle of four rotations, two half turns and two quarter turns coupled with one or two steps

\footnotetext{
${ }^{37}$ For a good introduction to this subject, see Sikora, Die Mechanisierung des Kriegers.

38 All the numbers given here refer to the equivalent lesson in the critical edition.

${ }^{39}$ For example, see the lesson 43 of the pike in the book printed in 1673.
} 
between each rotation $(\$ 3-5, \$ 10, \$ 15)$. The third is stepping straight but turning half around at each step (\$16).

The following table summarized the different type of content and gives the matching paragraphs in the $c$ and $e$ versions.

\begin{tabular}{|c|c|c|}
\hline Manipulations & c version & e version \\
\hline The three manners to carry the staff & introduction & introduction \\
\hline solo drill as a manner of salute & $\S 21$ & $\S 33$ \\
\hline \multicolumn{3}{|l|}{ Thrusts } \\
\hline thrusting front and back & $\S 1$ & $\S 1$ \\
\hline Spanish-thrusts alone & $\S 2-4$ & $\S 2-5$ \\
\hline jumping thrust & missing & $\S 31$ \\
\hline \multicolumn{3}{|l|}{ Parries } \\
\hline parries from above & $\S 8$ & $\S 11$ \\
\hline parries from below & $\S 9$ & $\S 12$ \\
\hline \multicolumn{3}{|l|}{ Strikes } \\
\hline Strike above the head followed by a Spanish-thrust & $\S 6$ & $\S 7, \S 9$ \\
\hline Strike above the head alone & $\S 7$ & $\S 8, \S 10$ \\
\hline Strikes from above & $\S 15-17$ & $\S 23-26$ \\
\hline Strikes from below & $\S 18-20$ & $\S 27-30$ \\
\hline \multicolumn{3}{|l|}{ Cuts } \\
\hline Cuts with one hand & $\$ 10$ & $\S 13-15$ \\
\hline moulinet moving straight while turning & $\S 11$ & $\S 16$ \\
\hline Cuts from the elbow & $\S 12$ & $\S 17-20$ \\
\hline moulinet in the four corners & $\S 13-14$ & $\S 21-22$ \\
\hline
\end{tabular}

Table 2: Summary of the lessons on the staff

\section{II.4. The French staff or baston à deux bouts}

\section{II.4.1. The French origin}

In the introduction of the $b$ version, Pasch claims that "this exercise at the present does not particularly flourish in Germany, while it is only common in France." He added in the title of the edition of 1670 that this material was "mostly translated, with diligence, from the French language to German." ${ }^{40}$ Does Pasch pretend that this material is French to make it look more prestigious? It is not impossible that the weapon was first given a German name, the hunting staff. However, I have not been able to find any other mention of the use of such a weapon in a context of war or self-defense. This hunting staff could then be the closest German weapon resembling the French staff. However, Pasch also attributes the material to the partisan in the first version, and later to the half-pike and the jumping-staff and only uses directly the French name, baston à deux bouts in later versions.

${ }^{40}$ Both translations by R. van Noort. 
The jumping-staff is certainly the name of a small spear. Based on a dictionary from 1662, the French military weapon called esponton, wich was a spear for officers, could be translated in German to half-pike or jumping-staff (eine halbe picke, ein springstock). ${ }^{41}$ One should also note that Pasch dedicated a specific chapter to the partisan in his 1673 publication with a largely different group of lessons. Finally, yet importantly, the illustrations delivered with the manuals unambiguously show a weapon with two similar points at each extremity. This does not fit with any half-pike or any other similar weapon. It seems to me that Pasch conserved such German terms in parallel of the French word, batton à deux bouts because, despite the trend for French vocabulary, this weapon was mostly unknown to his contemporary countrymen and did not have a proper name.

In parallel, the existence of a French cultural phenomenon around the weapon is unmistakable. I have been able to trace the persistence of the practice of staff fighting in France from the late fifteenth century through the nineteenth century. This was reinforced more recently by the discovery of an ordinance from 1501 only dedicated to staff play. Two points above all must be remembered, namely on the one hand that the Parisian fencing masters had to prove their skill with the long staff during their master examination in 1634. On the other hand, in France this weapon was associated to traveling workers above all social categories, which means that it was a very low class weapon! ${ }^{42}$

The long staff material is not the only part that has a French origin. Hazebroucq showed clearly that the dances presented by Pasch came from France, even if no other description for them exists from that period..$^{43}$ Something similar seems to have happened with the staff. There are only a few French technical sources that give details about how to fence with the French staff during the seventeenth century.

The only fencing master who mentions this weapon in his treatise is Besnard, in 1653 . He presents the staff with two ends as a weapon for artisans or other people of low social condition but does not give any advice for its use. ${ }^{44}$

In 1678, Louys de Gaya published a military treatise in which he briefly mentions the staff with two ends in the following terms:

We can also add to the weapons the staff, commonly called with both ends (because of iron spikes, which are at the two extremities) which is a straight and smooth piece of wood. It is somewhat heavier and thicker than a pike, and its length is six and a half feet between the ferrules. These ferrules hold in place two spikes protruding four and a half inches from the staff. One wears it under the hip as a halberd, but the

\footnotetext{
${ }^{41}$ Nathanael Duez, Le vray et parfait guidon de la langue francoise, p. 92.

${ }^{42}$ For the cultural history of the staff in France, see Dupuis, L'escrime au bâton, pp. 154-61. About the staff ordinance from Mazan, see Dupuis, Organization and Regulation of Fencing, p. 248.

43 Hazebroucq, La technique de la danse, pp. 96-118.

44 Charles Besnard, Le maistre d'arme libéral, p. 107. "Les merciers, chaudronniers et autres de basse condition, apprenoient les uns avec les autres à bien jouer de leurs bastons à deux bouts, desquels ils faisoient merveilles aux assemblées et foires quand ily arrivoit sédition."
} 
handling is different, because of all the variety of techniques it is possible to do with it. Half-moulinets can be used to assume a fencing guard, or during the approach. One can also use it to thrust or to beat. ${ }^{45}$

The physical description of the staff is very accurate and close to that given by Pasch. De Gaya also mentions moulinets similar to those in the lessons of Pasch, but he remains too vague to make a proper comparison. The description given by Jacques Collombon in 1650 in his Traité de l'exercice militaire contains a large list of technical vocabulary, which is a much better source to compare with Pasch's techniques. The entire section is difficult to understand, but I have attempted a partial translation given below, and a complete reproduction in extenso in the appendix.

The staff with two ends can be carried in two ways on the shoulder or by counterweight, the arm stretched out below. When we are in fear, one must present the tip, thrust him, do a false rising strike to force him to get back. Then one must turn the face and the staff; thrust two times front and back, turning oneself. Then follow the false rising strikes on both sides [...], then the moulinet thrusting behind, doing it twice while parrying, then moulinet with a discharge, do it twice switching hands. Then the moulinet stepping forward, [...] then stop to see which way to go and pull the four thrusts forward, backward, act as one, stay in a close place [...] That is all the play of the staff with two ends. ${ }^{46}$

Collombon mentions many actions that sound similar to the lessons of Pasch. For example, Pasch describes carrying the staff below the outstretched arm in his introduction. Pasch also proposes to thrust forward and backward ( $\$ 1)$. Many variations of moulinets are presented in both works, even if it is difficult to link Collombon's passage precisely to Pasch's lessons. Collombon tells us to switch hands, stepping forward while doing moulinets, and Pasch proposes many exercises that could fit this description. The "discharges" of Collombon could possibly be linked to some of the cuts of Pasch, for example the cut done with one hand $(\$ 13)$ or the cuts done from the elbow (\$17).

However, it is difficult to link some techniques mentioned by Collombon to lessons of Pasch. For example the false rising strikes do not exactly match the strikes from below of Pasch (\$27), and Pasch proposes only two types of thrusts in comparison to the four thrusts mentioned by Collombon. The French author also proposes many combinations with the moulinets, which do not match Pasch's lessons, such as combining a moulinet

\footnotetext{
45 Louis de Gaya, Traité des armes, pp. 38-39: Nous pouvons encore mettre au nombre des Armes le Bâton, que nous appellons communement à deux bouts (à cause des pointes de fer qui sont aux deux extremitez) qui est d'un brin de bois bien droit \& bien uny, quelque peu plus pesant \& plus gros que celuy d'une Pique, dont la longueur est de six pieds \& demy entre les viroles, qui accolent les deux pointes saillantes hors du Baston de quatre pouces \& demy. On le porte sous hanche comme la Hallebarde; mais le maniement en est different: parce que de toutes les manieres on en peut faire le demy-moulinet pour se mettre en garde, \& se servir aux approches, ou de la pointe ou de l'estramacon. ${ }^{46}$ Collombon, pp. 15-16.
} 
with a thrust when Pasch only combines thrusts with vertical strikes. Furthermore, nothing in the short text of Collombon can be understood as working on the four faces or corners, though this seems to be fundamental in Pasch's exercises.

Ultimately, there are many kindred techniques that argue for confirming the assertion of a French origin to the staff material of Pasch.

However, it is very unlikely that this staff material has been translated directly from French to German. The style, the pedagogy, and the organization of the text are similar in many points to those used in the other sections of Pasch's works. There are also no known French works that could be compared in size and content. Finally but significantly, this assertion appears in the title of only one of the three known editions of the version e. One should also remember that this book was dedicated to duke Augustus himself. Hence, it seems that Pasch tried to give more value to his work by attributing a French origin not only for the material but also for the text.

\section{II.4.2. Posterity}

It seems that the works produced by Pasch have garnered more attention from historians for the series of engravings than for their content. ${ }^{47}$ Even Anglo, in his excellent essay on representations of movement in fencing, war and dance, forgot to mention Pasch, although he was probably the only author who produced a technical treatise for each of them!48

This also concerns the French staff material from Pasch, which was never republished in German after Pasch. At this stage, there is no evidence that the stick Pasch has been emulated in Germany. However, this apparent disaffection has also been the case in France. The French military books seem to have forgotten this weapon by the end of the seventeenth century. Neither Mannesson in 1684 nor Giffart in 1696 mention it in their books. ${ }^{49}$ Moreover, during the eighteenth century, the staff with two ends disappeared not only from the French military scene, but also from the common vocabulary. This does not mean that the practice of staff fighting disappeared in France, but it seems to have been overshadowed in this country by the walking stick. One must wait until the second half of the nineteenth century to find technical manuals on the French staff, mostly from military contexts. However, there are many similarities between the military staff techniques from the nineteenth century and those presented by Pasch. In both the movements consist of large circles and moulinets to provide a security area around the fighter. Thrusts can be provided front and back, the fighter is invited to work facing four directions, using alternatively wide horizontal and vertical cuts. These specificities can also be found in French walking sticks techniques dedicated to face many opponents. ${ }^{50}$ It would require a more detailed study, but it is very tempting to see one of the ancestors of the French walking stick of the nineteenth century in the staff techniques presented by Pasch.

\footnotetext{
47 Anglo, Martial Arts, pp. 48-60. Wellmann, Hand und Leib, pp. 20-22.

48 Anglo, L'escrime, la danse et l'art de la guerre.

49 Allain Manesson Mallet, Les travaux de Mars. Pierre Giffart, L'Art militaire françois.

${ }^{50}$ Dupuis, L'escrime au bâton, especially pp. 171 and 175-76.
} 


\section{II.5. Conclusion}

Johann Georg Pasch was the perfect example of the educated German middle-class that rose up after the Thirty-Year Wars. After having studied in renowned Universities, he entered into the service of the Duke of Saxe-Weissenfels. He then took the opportunity to publish books with the help of different patrons. However, the subjects differed drastically from those of other authors of his time: all of his books are pedagogical manuals dedicated to the physical instruction of the young aristocracy.

Thanks to the French cultural influence on the German court, Pasch was inclined to include the French staff in his teachings and publications. It is paradoxical to see a weapon relegated in France to the lower-class people and ignored in the French fencing treatises, being exported to the German court. The French origin adorned it with a virtue such that in 1670 this weapon received an edition dedicated directly to a Prince-Elector.

This allows us to have a technical source of great value over two hundred years before the first French technical treatise dealing with this weapon appeared.

The existence of several known editions gives the opportunity to study in detail the evolution of a technical treatise. From a presumed preliminary manuscript version of which we only know the chapter titles, Pasch published an educational treatise, then enriched it with both illustrations and text improvements. Finally, he amply supplemented the text and renewed the illustrations.

\section{EDITION OF THE STAFF MATERIAL}

\section{III.1. Transcription rules}

I have followed most of the transcription rules adopted by Schlottermüller in his edition of the dance manual.

The syntax and the grammar from the original text have been strictly respected, in particular the inversions between dative and accusative.

The symbol " $\mathrm{e}$ " above a vowel in the original texts means a diphthong and is transcribed with a dieresis following the modern custom in German. The long and short "s" have all been transcribed with the letter "s". When the two letters "sz" are ligatured, they are transcribed using the letter " $\beta$ ". In one unique case, the letter " $v$ " that has the value of "u" is transcribed with "u" (attaquiret). The numbers are all emphasized with a final point in the original editions, as was the custom in that time (for example 10. 20. und 30.). These points have not been reproduced here.

All versions contained a large number of contracted forms for right and left (rechts and lincks) or their derivative forms. All these contracted forms have been developed in this edition. There are some rare contraction marks. The most common contraction is the nasal mark, a tilde above a letter. For example above the " $\mathrm{n}$ " in weñ which means wenn 
(\$1). Otherwise, some words have been shortened like erstl. (\$7) and neml. (\$12). These have also all been developed without mention here as erstlich and nemlich.

All historical editions followed similar rules about the fonts used. The standard text was in Fractur, and Latin, French or Italian words were written in italic Roman. In the following edition, the standard German text is in standard Roman and the Latin or French words are emphasized in italic.

Except for rare interrogation and exclamation points, the original editions used the point to mark the end of a paragraph. Inside the paragraphs, the editor used only the slash. The following edition does not follow this old use of punctuation and commas and points have been introduced following modern rules.

Finally, the capitals above the names have been generalized in the modern manner for a German text. This rule is only partially applied inside the original editions.

\section{III.2. Organization of the edition}

I made the choice to present two different versions in a two columns presentation. The $c$ version from 1660 appears in the left column. The right column contains the critical edition, in other words an ideal version, based on the $e$ version with some improvements using the $f$ version.

The variation of underlining informs the reader of differences between the versions, with the help of additional notes. The meaning of each underlined section is explained below for each edition. It is important to note that only the significant modifications are emphasized and the spelling differences for a specific word have been neglected.

\section{III.2.1. Version $c$}

"Was das Fechten". this emphasizes a difference with the version $b$. An edition note gives the text from the previous version. If there is no such note, it means that it is an addition of version $c$ without any matching text in version $b$.

"bekand" this emphasizes a difference between version $c$ and the critical edition.

\section{III.2.2. Critical edition}

"florireet" this emphasizes a modification from version $c$, or an improvement taken from version $f$. In the latter case, an edition note has been added.

"Baston à deux bous, Jägerstock, halbe Pique oder der Springestock" this emphasizes a difference between version $e$ and version $f$, where the ideal version kept version $e$.

"yiertehalbe Ellen" this emphasizes parts that have been deleted in version $f$.

\section{III.2.3. Revision Notes}

The revision notes for each edition are located in a dedicated column beside the text. Most of these notes give the reader the text from another version for a specific passage. 
In some specific cases, the discussion is too long and requires a specific paragraph. In such cases, the note refers to its dedicated paragraph inside the following section.

\section{III.3. Specific notes}

To avoid confusion, the lesson number used in the following discussion is always that of the critical edition.

\section{III.3.1. Lesson 3}

The sentence In diesen Stockaden mustu dich jederzeit lincks herum kehren. Es wird aber glißiret und zugetreten wie in der vorhergehenden andern Lection is missing in version $\mathrm{f}$ and was replaced by two indications for the direction of rotation: lincks herumb hernach halbe herumb and ferner halb lincks herumb. These indications are less accurate than the text of the previous version. In my opinion, Pasch made these modifications to reduce the size of the paragraph.

\section{III.3.2. Lessons 14, 15, 18, 19, 20}

In these lessons, first added in version $e$, Pasch used the word Schlag instead of Hieb to refer to the strikes done. However, these lessons are all variants of lessons on the horizontal strikes, which are normally called Hiebe by Pasch.

These paragraphs have all been added in a late version and maybe Pasch used the word Scblag in its generic meaning here. To avoid any confusion, in these lessons I chose to substitute Hieb -or its plural form Hieben when convenient- for Schlag or Scbläge.

\section{III.3.3. Lesson 16}

Version $f$ differs from all other versions in the footwork. However, it appears to be a correction made by Pasch. The first foot position in the text is at the beginning: Wann nun zuletzt dein L. Fuß binten stehet. Version $f$ differs and indicates instead R. Fuß. Actually, picture 12 in version $c$ or picture 21 in the later versions depicts this position, and clearly shows the left foot forward.

This is also not coherent with the second part of the lesson, which begins with wenn nun dein recbten Fuß vorstehet. It explains how to do the movement backward, beginning with the right foot forward. To my understanding of the lesson, version $f$ is the correct one and I used this in the critical edition.

\section{III.3.4. Lesson 25}

Version $c$ substitutes the sentence weiter auff deine lincke Seite lincks herum und trit mit deinem rechten Fuß, folgends auff with the homeoteleuton folgends auff auff, which was likely an edition mistake. The following known edition, $e$, does not correct the mistake but removes one of the auff.

This mistake combines with another mistake, which appears also in version $c$ an inversion from rechten Fuß to lincken Fußjust before the previous mistake. The lesson became very 
confused, which could explain why Pasch chose to rewrite the paragraph entirely in his bilingual version $f$.

For all these reasons, I chose to publish the text from the last version $f$ instead of a corrected version in the style of the previous versions. 


\section{III.4. Edition}

\begin{tabular}{|l|} 
Version $c$ from 1660 \\
\hline Was das Fechten auff den Hieb und Stoß ist ${ }^{a}$, solches ist
\end{tabular}

Was das Fechten auff den Hieb und Sto S- in gnugsam bekand, weiln aber dieses Exercitium noch zur Zeit in trillen in der Pique und Teutschland nicht sonderlich bekand, sondern in Franckreich Fahnschwingen ist

nur bräuchlich. Als habe ich die Nothturfft zu seyn erachtet, zuvorhero ehe die Lectiones gesetzet werden, etwas davon zu melden: Was es für ein Instrument, wie lang es seyn muß, und was es für ein Nutzen hat.

Der Jägerstock_oder halbe Pique an sich selber nun, ist ein starcker Stock ohngefehr 4 Finger dicke und viertehalbe Ellen lang. Auf beyden Enden Spitzen, wordurch man sich im fall der Noth gegen 10,20 und 30 Mann welche blosse Degen haben wehren kan. Es scheinet zwar fast unmüglich zu seyn, wer aber desselben Wissenschafft hat, wird solches bekräfftigen müssen, doch muß solches nur geschehen im Nothfall.

Wann einer- etwan in einem Hause von vielen mit blossen a) $b: e r$ Degen ümbringet und sich befürchten müste, daß das Hauß gestürmet würde, so thete er besser. Er schlüge sich durch und reterirte sich an einen sichern Ort, als daß er wartete biß sie ins b) $b$ : und sich auff den raumen Platze Hauß kämen, und er als dann den Stock in der Enge nicht gebrauchen könte. Oder wann er auff offener Gassen von vielen mit Degen attaquiret würde, so kan er sich ebenfalß auffhalten und auff den ren raumen Platzen ${ }^{\mathrm{b}}$ so lange wehren, biß Leute darzu kommen, wie denn in diesen Exercitio dergleichen Lectiones seyn, daß man sich über eine Viertelstunde auff einer Stelle wo Raum ist, gegen 20 oder 30 wehren kan, daß muß aber alles im Nothfall geschehen dann keinen zu rathen! Daß er sich muthwillig in Gefahr gebe wie dann auch andere Exercitia als Fechten, Ringen und dergleichen in der Noth und zur Defension nur sollen gebrauchet werden.

Ist also erstlich zu wissen nöthig das der Stock auff dreyerley Manier getragen werden kan. 


\section{Critical edition Teutschland nicht sonderlich floriret, sondern in Franckreich this edition. \\ nur bräuchlich. Als habe ich die Nothdurfft zuseyn erachtet, zuvorhero ehe die Lectiones gesetzet werden, etwas davon zu melden: Was es für ein Instrument? Wie lang es seyn muß ? Und was es vor ein Nutzen hat. ${ }^{a}$}

Notes

Was das Fechten auff den Hieb und Stoß sey, solches ist a) $f$ : this entire gnugsam bekandt, weiln aber dieses Exercitium noch zur Zeit in paragraph is missing in

Der Baston à deux bous, Jägerstock, halbe Pique oder der a) f: Die halbe Pique oder Springestock $^{\mathrm{a}}$ wie selbigen etzliche nennen an sich selber nun, Jägerstock

ist ein starcker Stock ohngefehr 4 Finger dicke und viertehalbe Ellen lang oder so lang als ein Mann, welcher ihn brauchen wil, reichen kanb. Auff beyden Enden Spitzen mit Schneiden, wie Num. 1 weisets, wordurch man sich im fall der Noth gegen vielele Mann welche blosse Degen haben wehren kan. Es scheinet b) $e$ : als ein Mensch reichen kan, welcher ibn brauchen will zwar fast unmüglich zuseyn, wer aber desselben Wissenschafft hat, wird es bekräfftigen müssen, doch muß solches nur geschehen im Nothfall.

Wann einer etwan in einem Hause von vielen mit blossen Degen umbringet und sich befurchten müste, das das Hauß gestürmet würde, so thät er besser. Er schlüge sich durch und reterirte sich an einen sichern Ort, als daß er wartete biß sie ins Hauß kämen, und er als dann den Stock in der Enge nicht gebrauchen könte. Oder wann er auf offener Gassen von vielen mit Degen attaquiret würde, so kan er sich ebenfalß aufhalten und auf den raumen-Platze so lange wehren, biß Leute darzukommen wie denn in diesen Exercitio dergleichen Lectiones seyn, daß man sich über eine halbe Viertelstunde auff einer Stelle wo Raum ist, gegen 20 oder 30 wehren kan, daß muß aber alles im Nothfall geschehen dann keinen zu rathen! $\mathrm{Daß}$ er sich muthwillig in Gefahr gebe wie dann auch andere Exercitia als Fechten, Ringen und dergleichen in der Noth und zur Defension nur sollen gebrauchet werden.

Ist also erstlich zu wissen nöthig das der Stock auff dreyerley Manier getragen werden kan.

c) e: 10, 20, und 30 


\begin{tabular}{|c|c|}
\hline Version $c$ from 1660 & Notes \\
\hline $\begin{array}{l}\text { Die erste Manier ist, wann du den Stock in der mitten mit rechter } \\
\text { Hand fassest, nimbst denselben unter deinen rechten Arm, daß } \\
\text { die eine Spitze hinten hoch, die andere aber forne niedrig ist, wie } \\
\text { N. } 1 \text { zeiget. }\end{array}$ & \\
\hline $\begin{array}{l}\text { Die ander Manier. Hälstu den Stock eben unter deinen rechten } \\
\text { Arm, wie vor, nur daß du deine rechte Hand in der Mitten des } \\
\text { Stocks verkehrest, das die Finger oben liegen wie N. } 2 \text { weiset. }\end{array}$ & \\
\hline $\begin{array}{l}\text { Bey der dritten Manier komt der Stock eben so unter deinen } \\
\text { rechten Arm, nur daß du deine lincke Hand auf den Stock und } \\
\text { deine rechte Hand auff deinen lincken Arm legest, wie N. } 3 \\
\text { weiset. Und auff solche Manieren kan der Stock in Marchieren } \\
\text { getragen werden, dafern du nun diese Lectiones vor Leuten } \\
\text { spielest so mache einen Reverentzwie N. 4 zeiget.a }\end{array}$ & $\begin{array}{l}\text { a) b: diese Lectiones } \\
\text { nach einander machen } \\
\text { wilst, so mache erstlich in } \\
\text { dem du den Stock unter } \\
\text { deiner rechten Arm hast, } \\
\text { daß die forderste Spitze } \\
\text { niedrig und die binderste } \\
\text { hoch ist, mit deinen rechten } \\
\text { Fuß und Stock einen } \\
\text { Reverentz. }\end{array}$ \\
\hline Nun folgen die Lectiones & \\
\hline $\begin{array}{l}\text { 1. Stelle }{ }^{a} \text { deinen lincken Fuß vor und den rechten zurück. Fasse } \\
\text { den Stock zwey Spannen von der einen Spitze mit deiner } \\
\text { lincken Hand und zwey Spannen von der andern Spitze mit } \\
\text { deiner rechten Hand, wie N. } 5 \text { zeiget, und wenn dich nun } \\
\text { etliche wollen vorn angreiffen, so glissire vor durch beyde } \\
\text { Hände und geschwinde wiederum zurück. Wann du auf die } \\
\text { lincke Seite vor und zurück glissiren wilst, so mustu mit deinen } \\
\text { rechten Fuß fort treten, doch daß dein lincker Fuß vor bleibet } \\
\text { und dein rechter hinten kömbt, und also in alle vier Ecken. Und } \\
\text { zu ieden mahl mit deine rechten Fuß fort getreten, du must dich } \\
\text { aber allezeit ümbsehen, bald hinder dich, bald auff die Seiten, } \\
\text { wo sie dich wollen angreiffen, dann an selbigen Ort must du } \\
\text { dich auch defendiren. Wann du nun diese Lection in alle vier } \\
\text { Ecken gemachet hast und also wiederumb so stehest, allwo du } \\
\text { angefangen, so glissire vorauß } \\
\text { den Stock an der einen Spitzen hast und mit der lincken den } \\
\text { Stock ohngefehr drey Spannen von selbiger Spitzen. }\end{array}$ & $\begin{array}{l}\text { a) b: Die Stellung. Als } \\
\text { Stelle... } \\
\text { b) b: und geschwinde } \\
\text { zurück was in another } \\
\text { place of the sentence, } \\
\text { after zurürce glißiren } \\
\text { wilst. } \\
\text { c) b: vorn raus }\end{array}$ \\
\hline
\end{tabular}




\section{Critical edition}

Notes

Die erste Manier ist, wann du den Stock in der mitten mit a) $f$ : replaced by unter rechter Hand fassest, nimbst denselben unter deinen rechten deinen recbten Arm nimbst Arm, daß die eine Spitze hinten hoch, die andere aber forne niedrig ist, ${ }^{a}$ wie N. 2 zeiget.

Die ander Manier. Hälstu den Stock eben unter deinen rechten Arm, wie vor, nur daß du deine rechte Hand in der Mitten des Stocks verkehrest, das die Finger oben liegen wie N. 3 weiset.

Bey der dritten Manier kompt der Stock eben so unter deinen a) e: Margiren, corrected rechten Arm, nur daß du deine lincke Hand auf den Stock und using the version $c$ as deine rechte Hand auf deinen lincken Arm legest, wie N. 4 this part was missing in weiset. Und auff solche Manieren kan der Stock in Marchieren a the verson $f$. getragen werden dafern du nun diese Lectiones vor jemanden Exerciren wilst_so mache einen Reverentz wie N. 5 zeiget.

Nun folgen die Lectiones

1. Stelle deinen lincken Fusz vor und den rechten zurück. Fasse den Stock zwey Spannen von der einen Spitze mit deiner lincken Hand und zwey Spannen von der andern Spitze mit deiner rechten Hand, wie N. 6 zeiget, und wenn dich nun jemand will forn angreiffen, so glißire vor durch beyde Hände wie N. 7 weiset, und geschwinde wiedrum zurück wie N. 8 zuersehen. Wann du auf die lincke Seite vor und zurück glißiren wilst, so mustu mit deinen rechten Fuß fort treten, doch das dein lincker $\mathrm{Fu}$ vor bleibet und dein rechter hinten kömt, und also in alle vier Ecken. Und zu jedenmahl mit deine rechten Fuß fort getreten, du must dich aber allezeit umbsehen, bald hinter dich, bald auf die Seiten, wo sie dich wollen angreiffen, dann an selbigen Ort mustu dich auch defendiren. Wann du nun diese Lection in alle vier Ecken gemachet hast und also wiedrumb so stehest, alwo du angefangen, so glißire vorauß daß du mit deiner rechten Hand den Stock an der einen Spitzen und mit der lincken den Stock ohngefehr drey Spannen von selbiger Spitzen hast, ${ }^{a}$ wie N. . 7.geshehehen.

a) $e$ : Hast was placed in a similar way than $b$ and $c$ versions. The actual place is an improvement of $f$. 


\begin{tabular}{|l|}
\hline Version $c$ from $\mathbf{1 6 6 0}$ \\
\hline 2. Die zwey Spaniol-Stockaden in alle vier Ecken, als glissire die \\
lincke an die rechte Hand biß ans dicke Ende und mit der \\
rechten Hand glissire nauß biß ans Ort wo die lincke Hand \\
gewesen ist und trit mit deinen rechten Fuß vor, wie N. 0. \\
zeiget. Glissire die rechte Hand an die lincke Hand biß ans \\
dicke Ende und mit der lincken Hand glissire nauß biß ans Ort \\
wo die rechte Hand gewesen ist und trit mit deinen lincken Fuß \\
vor und also mache es in alle vier Ecken biß du wiederum \\
zustehen kombst wo du angefangen hast und zwar iederzeit \\
lincks herumb.
\end{tabular}

3..$^{a}$ Mache die zwey Spaniol-Stockaden halb herum als erstlich hinder dich, hernach halb herumb wiederum an selbigen $\mathrm{n}$ Ort wo du erstlich gestanden dann auff deine lincke Seite ferner halb herum auff deine rechte Seite zuletzt wiederum an den Ort wo du zum Anfange gestanden.

In diesen Stockaden mustu_diche iederzeit lincks herum kehren.

Es wird aber glissiret und zugetreten wie in der vorhergehenden andern Lection. ${ }^{\mathrm{e}}$

4. Mache nur eine Spaniol-Stockade halb herumb als in dem du a) b: rechten Fußvor und stehest wie du hast angefangen. So mache eine Stockade hinder dich lincks halb herum und trit mit deinem rechten Fuß vor wieN. 7 zeiget. Hernach eine Spaniol-Stockade wiederum an den Ort wo du erstlich gestanden halb rechts herum und trit mit deinem lincken Fuß vor, weiter auff deine lincke Seite Lincks herum und trit mit deinem rechten Fuß vor folgends auff deine rechte Seite halb rechts herum und trit mit deinem lincken Fusz vor und zuletzt lincks herum an den Ort alwo du angefangen hast und trit mit deinem rechten Fuß For und mache noch eine Stockade. Es $\oint^{a}$ muß zu iedem Trit eine Spaniol-Stockade gemacht werden. $\mathrm{Zu}$ dieser Spaniol-Stockade glissirestu mit rechten und lincken Hand wie in den vorhergehenden Lectionibus gedacht worden. 


\section{Critical edition}

Notes

2. Die zwey Spaniol-Stockaden in allen vier Ecken, als glißire a) e: ans dicke Ende. die lincke an die rechte Hand biß an die Spitze ${ }^{a}$ und mit der rechten Hand glißire naus biß ans Ort wo die lincke Hand gewesen ist und tritt mit deinen rechten Fuß vor, wie N. 9. zeiget. Glißire die rechte Hand an die lincke Hand biß an die $\underline{\text { Spitze }}^{\mathrm{n}}$ und mit der lincken Hand glißire naus biß ans Ort wo die rechte Hand gewesen ist und tritt mit deinen lincken Fuß vor und also mache es in alle vier Ecken biß du wiedrumb zustehen kombst wo du angefangen hast und zwar jederzeit lincks herumb.

3. Mache die zwey Spaniol-Stockaden halb herum als erstlich a) See III.3.1. hinter dich hernach halb herumb wiedrumb an selbigen Ort wo du erst gestanden dann auff deine lincke Seiten ferner halb herumb auf deine rechte Seite zuletzt wiederum an den Ort wo du zum Anfange gestanden.

In diesen Stockaden mustu dich jederzeit lincks herum kehren. Es wird aber glißiret und zugetreten wie in der vorhergehenden andern Lection. ${ }^{a}$

4. Mache nur eine Spaniol-Stockade halb herumb als in dem du stehest wie du hast angefangen. So mache eine Stockade hinter dich lincks halb herum und trit mit deinen rechten $F u ß$ vor wie N. 10 zeiget. Hernach eine Spaniol-Stockade wiedrum an den Ort wo du erstlichen gestanden halb rechts herumb und tritt mit deinen lincken Fuß vor, weiter auf deine lincke Seite lincks herumb, und tritt mit deinen rechten Fuß vor folgends auf deine rechte Seite halb rechts herum und tritt mit deinen lincken Fuß vor und zuletzt lincks herumb an den Ort allwo du angefangen hast und trit mit deinen rechten Fuß vor und mache noch eine Stockade. Es muß zu jeden Tritt eine SpaniolStockade gemacht werden. Zu dieser Spaniol-Stockade glißirest du mit rechten und lincken Hand wie in den vorhergehenden Lectionibus gedacht worden.

5. Gleich wie die zwey Spaniol-Stockaden in alle vier Ecken gemacht werden, also kan es auch etzliche mahl vor und hinter sich geschehen. 


\begin{tabular}{|l|}
\hline Version $c$ from 1660 \\
\hline 5. Mache die Schläge über den Kopff und Spaniol-Stockade \\
darzu, nehmlich in dem du stehest wo du angefangen hast und \\
dein lincken Fuß vor, so glissire deine rechte Hand biß an deine \\
lincke-a. Greiff mit deiner lincken Hand unter deine Rechte und \\
glissire die lincke Hand biß an die Spitze des Stocks und trit mit \\
deinem lincken ${ }^{\text {bu }}$ Fuß vor wie N. 8 zeiget und schlage also zu. \\
Mache eine Spaniol-stockade und trit mit deinem lincken Fuß \\
vor, wie in der andern Lection gemeldet und also mache es in \\
alle vier Ecken biß du zustehen kömst wo du angefangen hast \\
und zwar iederzeit lincks herumb.
\end{tabular}

6. ${ }^{a}$ Mache die Schläge über den Kopff und Spaniol-stockade halb darzu halb herum wie du sie in alle vier Ecken gemacht hast, als erstlich hinder dich halb herum. Hernach wiederum an selbig Ort, wo du erstlich gestanden halb herum dann auff deine lincke Seite ferner halb herumb auf deine rechte Seiten. Zuletzt wiederum an deinen Ort wo du zum Anfang gestanden. b) b: muß ich mich Notes

a) b: lincke Hand b) this indication is a mistake corrected in the version $e$.

a) This paragraph has been reproduced twice in the version $c$.

In dieser Lection mustu dichb iederzeit lincks herumb kehren. Es wird aber glissiret und zugetreten wie in der vorhergehenden Lection.

7. Mache die Schläge über den Kopff ohne Spaniol-Stockaden a) $b$ : rechte Hand halb herumb als in dem du stehest wo du angefangen. So glissire deine rechte Hand biß an deine lincke. Greiff mit deiner lincken Hand unter deine rechtea und glissire die Lincke biß an die Spitze des Stockes. Trit mit deinem rechten Fuß halb lincks herum und schlage also zu wie N. 9 weiset. Glissire deine lincke Hand biß an deine rechte.a Greiff mit deiner rechten Hand unter deine lincke Hand und glissire die rechte Hand biß an die Spitze des Stockes. Trit mit deinen lincken Fuß halb rechts herum, daß du an den Ort kombst alwo du angefangen hast und schlage also zu. Glissire wiederum deine rechte Hand biß an deine lincke. Und greiff mit deiner lincken Hand unter deine rechte und glissire die lincke Hand biß an die Spitze des Stocks. Tritt mit deinen rechten Fuß Lincks herumb auff deine lincke Seite und schlage also zu. Glissire ferner deine lincke Hand biß an deine rechte. Greiff mit deiner rechten Hand unter deine lincke und glissire die rechte Hand biß an die Spitze des Stockes. Tritt mit deinem lincken Fuß 


\section{Critical edition}

Notes

6. Mache die Schläge über den Kopff und Spaniol-Stockade darzu, nehmlich in dem du stehest wo du angefangen hast und dein lincken Fuß vor, so glißire deine rechte Hand biß an deine Lincke wie N. 11 weiset. Greiff mit deiner lincken Hand unter deine Rechte und glißire die lincke Hand biß an die Spitze des Stocks und tritt mit deinem rechten $\mathrm{Fu}$ vor wie N. 12 zeiget und schlage also zu.

Mache eine Spaniol-Stockade und trit mit deinem lincken Fuß vor wie in der andern Lection gemeldet und also mache es in alle vier Ecken biß du zu stehen kömst wo du angefangen hast und zwar jederzeit lincks herumb.

7. Mache die Schläge über den Kopff und Spaniol-Stockade darzu halb herum wie du sie in alle vier Ecken gemacht hast, als erstlich hinter dich halb herum. Hernach wiederum an selbigen Ort wo du erstlich gestanden halb herum dann auf deine lincke Seiten ferner halb herum auf deine rechte Seiten. Zuletzt wiederum an deinen Ort wo du zum Anfange gestanden. In dieser Lection mustu dich jederzeit lincks herum kehren. Es wird aber glißiret und zugetreten wie in der vorhergehenden Lection.

8. Mache die Schläge über den Kopff ohne Spaniol-Stockaden halb herum als in dem du stehest wo du angefangen. So glißire deine rechte Hand biß an deine Lincke. Greiff mit deiner lincken Hand unter deine rechte und glißire die lincke biß an die Spitze des Stockes. Tritt mit deinen rechten Fuß halb lincks herum und schlage also zu wie N. 13 weiset. Glißire deine lincke Hand biß an deine rechte. Greiff mit deiner rechten Hand unter deine lincke Hand und glißire die rechte Hand biß an die Spitze des Stockes. Trit mit deinen lincken Fuß halb rechts herum, das du an den Ort kompst alwo du angefangen hast und schlage also zu. Glißire wiederum deine rechte Hand biß an deine lincke. Greiff mit deiner lincken Hand unter deine rechte und glißire die lincke- biß an die Spitze des Stocks. Trit mit deinen rechten Fuß lincks herumb auf deine lincke Seite und schlage also zu. Glißire ferner deine lincke Hand biß an deine rechte. Greif mit deiner rechten Hand unter deine lincke und glißire die rechte Hand biß an die Spitze des Stockes. Tritt 


\begin{tabular}{|l|l|}
\hline Version $c$ from 1660 & Notes \\
\hline halb rechts herumb und schlage also zu. Glissire zuletzt deine \\
rechte Hand biß an deine lincke und greiff mit deiner lincken \\
Hand unter deine rechte Hand und glissire die lincke Hand biß \\
an die Spitze des Stocks. Tritt mit deinem rechten Fuß Lincks \\
herum auff deine lincke Seite, daß du an den Ort zustehen komst \\
alwo du angefangen und schlage also zu.
\end{tabular}




\section{Critical edition}

Notes

mit deinen lincken $\mathrm{Fu} ß$ halb rechts herumb und schlage also zu. Glißire zuletzt deine rechte Hand biß an deine lincke und greiff mit deiner lincken Hand unter deine rechte Hand und glißire die lincke Hand biß an die Spitze des Stocks. Tritt mit deinen rechten Fuß lincks herum auf deine lincke Seite, das du an den Ort zustehen komst allwo du angefangen und schlage also zu. Und mache eine Spaniol-Stockade.

9. Wie du die Schläge über den Kopff und Spaniol-Stockade in Quadrat machest. Also kan es auch etliche mahl vor und hinter sich geschehn.

10. Gleich wie die Schläge über den Kopff ohne SpaniolStockaden in alle vier Ecken gemachet werden. Also kan auch solches vor und hinter sich geschehen.

11. Mache die Paraden von oben vor und zurück. Alß setze die Füsse gleich und fasse den Stock mit rechter und lincker Hand in die mitten doch das deine Finger in der rechten Hand oben und in der lincken Hand unten kommen. Halt den Stock vor dir das die eine Spitze bey deiner lincken Hand und die ander bey deiner rechten Hand ist, wie N. 14 zeiget.

$\mathrm{Laß}$ die Spitze welche bey deiner lincken Hand ist von oben von dir warts bey deinen lincken Fuß vorbey gehn, wie N. 15 weiset, hernach eben selbige Spitze bey deinen rechten Fuß vorbey wie N. 16 zuersehen und so weiter und gehe etzliche Schritt vor und zurück.

12. Mache die Paraden von unten vor und zurück. Nemlich in dem du mit deinen Füssen gleich stehest und den Stock in den Händen wie in vorigen Paraden hälst. So lasse die Spitze welche bey deiner lincken Hand ist von unten hinter dir warts bey deinen lincken Fusz vorbey gehen, wie N. 17 zeiget, hernach eben selbige Spitze bey deinen rechten Fuß vorbey wie N. 18 weisset und so weiter. Und gehe etzliche Schrit vor und zurück wie vorhin. 
\begin{tabular}{|l|} 
Version $c$ from 1660 \\
10. Tritt mit deinem lincken Fuß zurück und verkehre deine
\end{tabular} rechte Hand. Glissire eine Spitze hinter dich bey deiner lincken Seiten vorbey wie N. 11 weiset und mache die Hiebe auff beyden Seiten vor und zurück als in dem du so stehest. So haue einen gantzen Circkel mit deiner rechten Hand rechts herumb und tritt mit deinen lincken Fuß vor. Fasse den Stock mit deiner lincken Hand daß die Finger unten kommen und glissire eine Spitze wiederum hinter dich bey deiner rechten Seiten vorbey und haue mit deiner lincken Hand Lincks herumb einen gantzen Circkel. Tritt mit deinen rechten Fuß vor und fasse den Stock mit deiner rechten Hand daß die Finger unten kommen und glissire nochmahls eine Spitze hinter dich bey deiner lincken Seiten vorbey und mache noch solche vier Hiebe. Wann nun zuletzt dein rechter Fuß vor komt und du wiederum die Spitze des Stocks bey deiner lincken Seiten vorbey glissiret hast. So haue einen gantzen Circkel mit rechten Hand rechts herum und tritt mit deinem rechten Fuß zurück. Fasse den Stock mit deiner lincken Hand daß die Finger unten kommen und glissire eine Spitze hinter dich bey deiner rechten Seiten vorbey. Haue einen gantzen Circkel mit lincker Hand lincks herum und tritt mit deinen lincken Fuß zurück. Fasse den Stock mit deiner rechten Hand das die Finger unten kommen und glissire eine Spitze hinter dich bey deiner lincken Seiten vorbey und mache noch solche vier Hiebe. 


\section{Critical edition}

Notes

13. Tritt mit deinen lincken Fuß zurück und verkehre deine rechte Hand. Glißire eine Spitze hinter dich bey deiner lincken Seiten vorbey wie N. 19 weiset und mache die Hiebe auf beyden Seiten vor und zurück als in dem du so stehest. So haue einen gantzen Circkel mit deiner rechten Hand rechts herum und trit mit deinen lincken Fuß vor. Fasse den Stock mit deiner lincken Hand das die Finger unten kommen und glißire eine Spitze wiederum hinter dich bey deiner rechten Seiten vorbey wie N. 20 zuersehen, und haue mit deiner lincken Hand Lincks herum einen gantzen Circkel. Tritt mit deinen rechten Fuß vor und fasse den Stock mit deiner rechten Hand das die Finger unten kommen und glißire nochmahls eine Spitze hinter dich bey deiner lincken Seiten vorbey und mache noch etzliche solche Hiebe. Wann nun zuletzt dein rechter Fuß vor kommt und du wiederumb die Spitze des Stocks bey deiner lincken Seiten vorbey glissiret hast. So haue einen gantzen Circkel mit rechten Hand rechts herumb und tritt mit deinen rechten Fuß zurück. Fasse den Stock mit deiner lincken Hand das die Finger unten kommen und glissire eine Spitze hinter dich bey deiner rechten Seiten vorbey. Haue einen gantzen Circkel mit lincker Hand lincks herum und tritt mit deinen lincken Fuß zurück. Fasse den Stock mit deiner rechten Hand das die Finger unten kommen und glißire eine Spitze hinter dich bey deiner lincken Seiten vorbey und mache noch etzlichene solchene Hiebe.

14. Diese Lection kan in alle vier Ecken jederzeit halb herumb mit zweya Hiebeb gemachet werden.

a) $f$ : einen which is a mistake.

b) See III.3.2.

15 Diese Lection kan in alle vier Ecken jederzeit halb herumb a) See III.3.2. mit einen Hiebea gemachet werden. 
Version $c$ from 1660
11. Wann nun zuletzt dein lincker Fuß hinten stehet so fasse den Stock mit rechten Hand daß die Finger oben kommen eine Spanne von der lincken Hand in dem der Stock lincks herumb gehet und du deine lincke Hand bey der Spitze hast, das die Finger unten kommen wie N. 12 zeiget, und mache die Hiebe mit beyden Händen vor und zurück als in dem dein lincken Fuß hinten stehet. So wirff deinen rechten Fuß nach deiner lincken Seiten hinter deinen rechten Fuß herumb, daß du dein Gesichte auff die andre Seite kehrest und mit den Füssen gleich stehest und haue mit beyden Händen einen gantzen Circkel lincks umb den Kopff. Wirff deinen rechten Fuß uber deinen lincken herum daß deine Füsse gleich zu stehen kommen und du zu stehen komst wie du erst gestanden und haue mit beyden Händen einen gantzen Circkel Lincks umb den Kopff. Mache noch vier solche Hiebe und trit $\mathrm{zu}$ ieden $\mathrm{zu}$ wie gemeldet worden.

Wenn nun dein rechten Fuß vorstehet, so mache diese Hiebe zurück als würff deinen rechten Fuß übern lincken Fußh nach deiner lincken Seiten zurück ${ }^{i}$ daß du dein Gesichte auff die andere Seite wendest und haue mit beyden Händen einen gantzen Circkel lincks umb den Kopff. Wirff ferner deinen lincken Fuß nach deiner lincken Seiten hinter deinen rechten Fuß herumb und haue mit beyden Händen einen gantzen Circkul Lincks umb den Kopff. Mache noch solche vier Hiebe biß du an den Ort kommest alwo du angefangen und tritt zu ieden Hieb zurück wie albereit gemeldet worden. Bey diesen Hieben kehrestu dich allezeit auff deine rechte oder lincke Seiten und stehest mit deinen Füssen gleich. 
\begin{tabular}{l} 
Critical edition \\
\hline 16. Wann nun zuletzt dein rechter $^{\mathrm{a}} \mathrm{Fu}$ hinten stehet so fasse
\end{tabular} den Stock mit rechten Hand daß die Finger oben kommen eine Spanne von der lincken Handen in dem der Stock lincks herumb gehet und du deine lincke Hand bey der Spitze hast, das die Finger unten kommen wie N. 21 zeiget, und mache die Hiebe mit beyden Händen vor und zurück als in dem dein lincken Fuß hinten stehet. So wirf deinen rechten ${ }^{a} \mathrm{Fuß}$ nach deiner lincken Seiten $\underline{\operatorname{vor}}^{\mathrm{c}}$, daß du dein Gesichte auff die andre Seite kehrest und mit den Füssen gleich stehest und haue mit beyden Händen einen gantzen Circkel lincks ümb den Kopff. Wirff deinen lincken Fuß hinter deinen rechten ${ }^{\text {d }}$ herum daß deine Füsse gleich zustehen kommen und du zustehen kompst wie du erst gestanden und haue mit beyden Händen einen gantzen Circkel Lincks umb den Kopff. Mache noch etzlichesolche Hiebe und tritt zu jeden zu wie gemeldet worden.

Wenn nun dein rechten Fuß vorstehet, so mache diese Hiebe zurück als wirff deinen rechten Fuß übern lincken Fuß nach deiner lincken Seiten zurück ${ }^{i} \mathrm{da}$ du dein Gesichte auf die andre Seite wendest und haue mit beyden Händen einen gantzen Circkel lincks umb den Kopff. Wirff ferner deinen lincken Fuß nach deiner lincken Seiten hinter deinen rechten Fuß herumb und haue mit beyden Händen einen gantzen Circkel Lincks umb den Kopff. Mache noch etzliche solche Hiebe biß du an den Ort kommest alwo du angefangen und tritt zu jeden Hieb zurück wie albereit gemeldet worden. Bey diesen Hieben kehrestu dich allezeit auff deine rechte oder lincke Seiten und stehest mit deinen Füssen gleich.

\section{Notes}

a) See III.3.3

c) $e$ : binter deinen rechten Fuß herumb This is not coherent with the initial foot position, see notes $a$ and $d$.

d) e: deinen rechten Fuß über deinen lincken.

i) $f: z u$ 


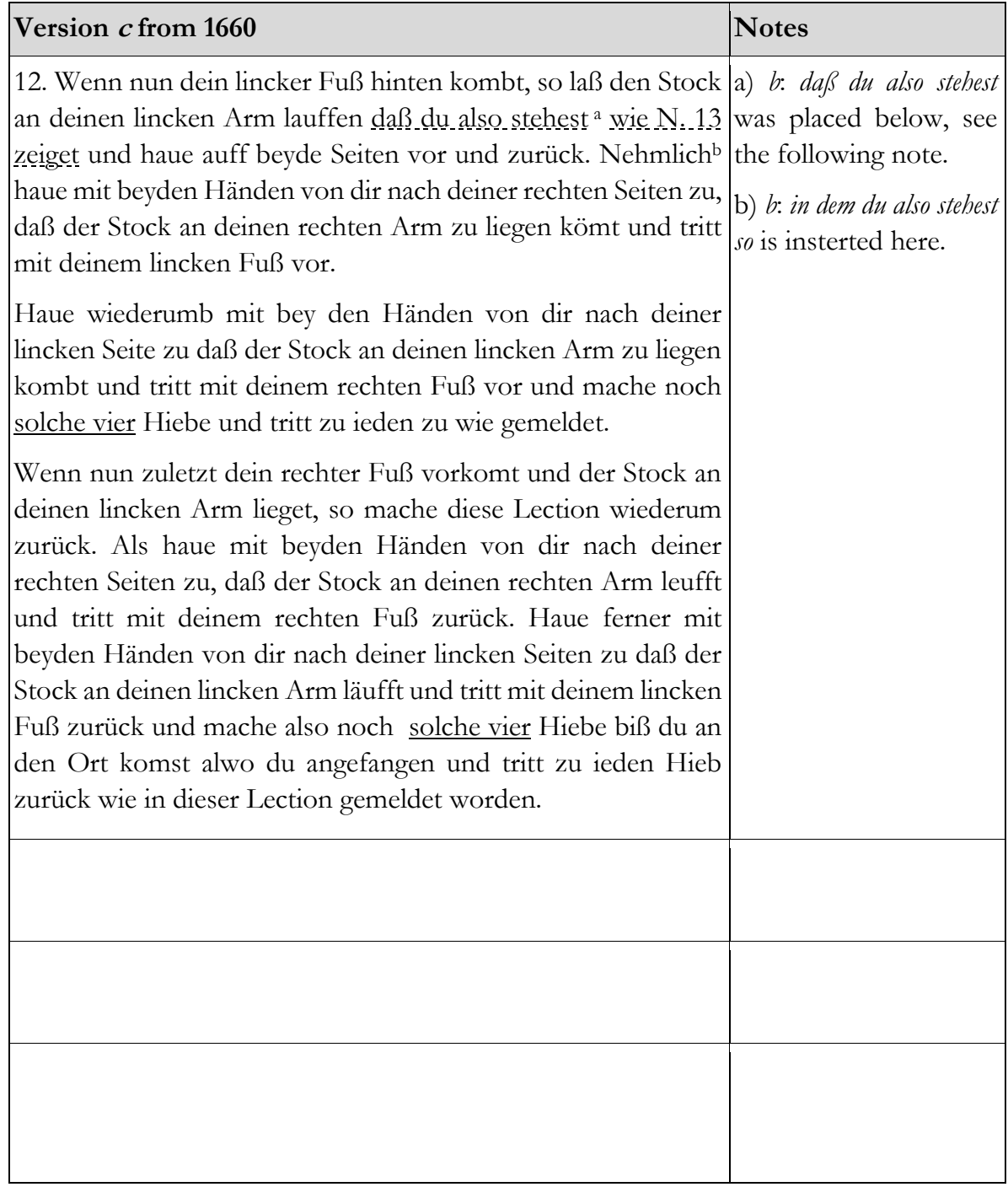




\section{Critical edition}

Notes

17. Wenn nun dein lincker Fuß hinten kompt, so laß den Stock an deinen lincken Arm lauffen daß du also stehest ${ }^{a}$ wie N. 22 zeiget und haue auff beyde Seiten vor und zurück. Nehmlich ${ }^{\mathrm{b}}$ haue mit beyden Händen von dir nach deiner rechten Seiten $\mathrm{zu}$, das der Stock an deinen rechten Arm zu liegen kommt und tritt mit deinen lincken Fuß vor wie N. 23 weiset.

Haue wiederumb mit bey den Händen von dir nach deiner lincken Seite zu das der Stock an deinen lincken Arm zu liegen kommt und tritt mit deinem rechten Fuß vor und mache noch etzliche solche Hiebe und tritt zu jeden zu wie gemeldet.

Wann nun zuletzt dein rechter Fuß vorkommt und der Stock an deinen lincken Arm lieget, so mache diese Lection wiederum zurück. Als haue mit beyden Händen von dir nach deiner rechten Seiten zu das der Stock an deinen rechten Arm läufft und tritt mit deinen rechten Fuß zurück. Haue ferner mit beyden Händen von dir nach deiner lincken Seiten zu das der Stock an deinen lincken Arm läufft und tritt mit deinen lincken Fuß zurück und mache also noch etzlichene solchene Hiebe biß du an den Ort komst alwo du angefangen und tritt zu jeden Hieb zurück wie in dieser Lection gemeldet worden.

18. Diese Lection kanstu in alle vier Ecken mit zwey Hiebea ${ }^{a}$ ) See III.3.2. machen.

19. Diese Lection kanstu auch in alle vier Ecken iederzeit halb a) See III.3.2. herum mit zwey Hiebe ${ }^{a}$ machen.

20. Diese Lection kan auch in alle vier Ecken iederzeit halb a) See III.3.2. herum mit einem Hieba gemachet werden, zuletzt mache ich zwey Hiebea . 
\begin{tabular}{|l|l}
\hline Version $c$ from 1660 & Notes
\end{tabular}

13. Nun folgen die Hiebe rund herumb Rechts. Als in dem dein rechter Fuß vorstehet, so tritt mit deinem lincken Fuß auff deine rechte Seite in einem Winckel und haue einen gantzen Circkel Rechts umb den Kopff wie in der vorgehenden Lection geschehen. Tritt ferner mit deinen lincken Fuß in den andern Winckel und haue einen gantzen Cirkul Rechts ümb den Kopff auf diese Art in den dritten und vierten Winckel und tritt zu ieden Hiebe welchen du Rechts ümb den Kopff thust. Trit mit deinen lincken $F u ß$ fort biß dein Lincker vor zu stehen kömbt und du an den Ort stehest alwo du angefangen. ${ }^{c}$

14. Mache diese Hiebe Lincks rund herum in alle Seite oder Ecken wie du sie recht gemacht hast nur daß dieses Lincks geschicht. Auch Lincks herum hauest und mit deinem rechten Fuß allezeit fort tritst.

Wenn du nun zuletzt dein Gesichte hinwendest und stehest wo du hast angefangen dein rechter Fuß auch vorstehet, so setze deinen rechten Fuß zurück und glissire den Stock bey deiner rechten Seiten vorbey, daß deine lincke Hand an der Spitze und deine rechte Hand zwey Spannen darvon ist.

15. Wenn nun dein rechter Fuß zurück stehet und du den Stock bey deiner rechten Seiten vorbey glissiret hast, so mache die a) $b$ : nemlich dein rechter Schläge von oben herunter in aller vier Ecken. Alß in dem dein here lincker Fuß vorstehet. So schlage von oben herunter und trit mit deinem rechten Fuß vor wie N. 14 zeiget. Glissire bey deiner lincken Seiten vorbey, daß deine rechte Hand an die Spitze und die lincke Hand zwey Spannen von der Spitze kömt, und schlage wiederum von oben herunter und trit mit deinem lincken $F u ß$ vor und also in alle vier Ecken biß du an den Ort wiederum kommest, allwo du angefangen und zwar iederzeit lincks herum. Wenn du nun so stehest wie du diese Lection angefangen ${ }^{a}$ und bey deiner rechten Seiten vorbey glissiret hast, daß deine lincke Hand an der Spitze des Stocks und deine rechte Hand zwey Spannen darvon. 


\section{Critical edition}

Notes

21. Nun folgen die Hiebe rund herumb Rechts. Als in dem dein rechter Fuß vorstehet, so tritt mit deinem lincken Fus auff deine rechte Seiten in einem Winckel und haue einen gantzen Circkel Rechts umb den Kopff wie N. 24 zeiget. Tritt ferner mit deinem lincken Fus in den andern Winckel und haue einen gantzen Cirkel Rechts umb den Kopff auf diese Art in den dritten und vierdten Winckel und tritt zu jeden Hiebe welchen du Rechts ümb den Kopff thust. Zu tritt mit deinen lincken Fus fort bis dein lincker vor zustehen kömbt und du an den Ort stehest allwo du angefangen. ${ }^{a}$

22. Mache diese Hiebe lincks rund herum in alle vier Winckel wie du sie Recht gemacht hast nur dasz dieses Lincks geschicht. Auch Lincks herum hauest und mit deinem rechten Fusz allezeit fort tritest $\mathrm{t}^{\mathrm{b}}$ wie N. 25 weiset.

Wenn du nun zuletzt dein Gesichte hinwendest und stehest wo du hast angefangen dein rechter Fuß auch vorstehet, so setze deinen rechten Fuß zurück und glißire den Stock bey deiner rechten Seiten vorbey, daß deine lincke Hand an der Spitze und deine rechte Hand zwey Spannen darvon ist, wie N. N. 26 zu ersehen.

23. Wenn nun dein rechter Fuß zurücke stehet und du den Stock bey deiner rechten Seiten vorbey glißiret hast so mache die Schläge von oben herunter in aller vier Ecken. Alß in dem dein lincker Fuß vorstehet. So schlage von oben herunter und tritt mit deinem rechten Fuß vor wie N. 27 zeiget. Glißire bey deiner lincken Seiten vorbey daß deine rechte Hand an die Spitze und die lincke Hand zwey Spannen von der Spitze komt wie N. 28 weiset, und schlage wiederum von oben herunter und tritt mit deinem lincken Fuß vor wie N. 29 zuersehen und also in alle vier Ecken biß du an den Ort wiederumb kömmest, allwo du angefangen und zwar jederzeit lincks herum. Wenn du nun so stehest wie du diese Lection angefangen und bey deiner rechten Seiten vorbey glißiret hast, das deine lincke Hand an der Spitze des Stocks und deine rechte Hand zwey Spannen darvon.

a) $f$ : shortened and replaced by und also in alle vier Winckel. alle or 


\section{Version $c$ from 1660 \\ 16. So mache diese Schläge von oben herunter in alle vier Ecken halb herum. Alß erstlich hinter dich hernach wiederum an selbigen Ort wo du erstlich gestanden. Dann auff deine lincke Seite hernach halb herum auff deine rechte Seiten zuletzt wiederum an den Ort wo du anfangs gestanden in diesen Schlägen muß ich mich iederzeit lincks herum kehren. Es wird aber glissiret und zugetreten wie in der vorhergehenden Lection. Wann nun dein lincker Fuß vorstehet und du bey deiner rechten Seiten vorbey glissiret hast.}

Notes

17. So mache nur einen Schlag von oben herunter in alle vier Ecken, alß erstlich hinter dich lincks halb herum und trit mit deinem rechten Fuß vor, hernach wiederum an den Ort wo du erstlich angefangen rechts herum und trit mit deinem lincken ${ }^{a}$ $\mathrm{Fu} ß$ vor, folgends $\mathrm{b}$ auff deine lincke Seite lincks herum und trit mit deinem rechten Fuß, folgends auffc deine rechte Seite halb Rechts herum und tritt mit deinem lincken Fuß vor und zuletzt Lincks herum an den Ort, allwo du angefangen hast. Und trit mit deinem rechten $\mathrm{Fu} \beta$ vor. In dieser lection wird glissiret wie in der $^{\mathrm{d}}$ vorhergehenden lection.

18. Mache die Schläge von unten herauff in alle vier Ecken wie N. 15 zeiget. In dieser Lection wird glissiret und zugetreten wie in der funffzehenden lection, nur daß du von unten herauff nach des Adversarii Ellenbogen schlägest.

19. Mache die Schläge von unten herauff in alle vier Ecken halb herum. In dieser Lection wird glissiret und zugetreten wie in der sechzehenden Lection. Nur daß du von unten herauff nach des Adversarii Ellenbogen wie in voriger Lection schlägest. ${ }^{b}$

20. Mache nur einen Schlag von oben herunter in alle vier Ecken. In dieser Lection wird glissiret und zugetreten wie in der siebenzehenden Lection. Nur daß du von unten herauff nach der Adversarii Ellenbogen schlägest.

a) rechten in $c$ and $e$ version rechten, which seems to be a mistake. See III.3.4.

b) $b$ : weiter

c) See III.3.4

x) b: wie die 


Critical edition
24. So mache diese Schläge von oben herunter in alle vier
Ecken halb herum. Als erstlich hinter dich ${ }^{\text {a }}$ hernach wiederum
an selbigen Ort wo du erstlich gestanden. ${ }^{a}$ Dann auf deine
lincke Seite hernach halb herumb auf deine rechte Seiten zuletzt
wiederum an den Ort wo du anfangs gestanden in diesen
Schlägen must du dich iederzeit lincks herum kehren. Es wird
aber glißiret und zugetreten wie in der vorhergehenden Lection.
Wann nun dein lincker Fuß vorstehet und du bey deiner
rechten Seiten vorbey glißiret hast.

25. ${ }^{\text {a }}$ So mache nur einen Schlag von oben herunter in alle vier a) See III.3.4 Ecken. Als erstlich halb lincks hinter dich, hernach wiederumb an den Ort wo du erstlich angefangen halb rechts. Folgends auff deine lincke Seite dann halb Rechts herumb nach deiner rechten Seiten und zuletzt lincks herumb an den Ort allwo du angefangen hast und machest zuletzt zwey Schläge.

26. Gleich wie die schläge von oben herunter in alle vier Ecken a) e: können sie auch. gemacht werden. Also kan auch solches ${ }^{a}$ vor und hinter sich gemacht geschehen. ${ }^{\mathrm{b}}$

b) $e$ : werden.

27. Mache die Schläge von unten herauff in alle vier Ecken wie N. 30 zeiget. In dieser Lection wird glißiret und getreten wie in der drey und zwantzigsten Lection, nur daß du von unten herauff nach des Adversarii Ellebogen schlägest.

28. Mache die Schläge von unten herauff in alle vier Ecken halb a) e: ein und zwantrigsten. herum. In dieser Lection wird glißiret und zugetreten wie in der vier und zwantzigstena Lection. Nur daß du von unten herauff nach des Adversarii Ellebogen wie in voriger Lection schlägest

29. Mache nur einen Schlag von unten herauff in alle vier Ecken. In dieser Lection wird glißiret und zugetreten wie in der zwantzigsten. fünf und zwantzigsten a Lection. Nur daß du von unten herauff nach der Adversarii Ellebogen schlägest. 


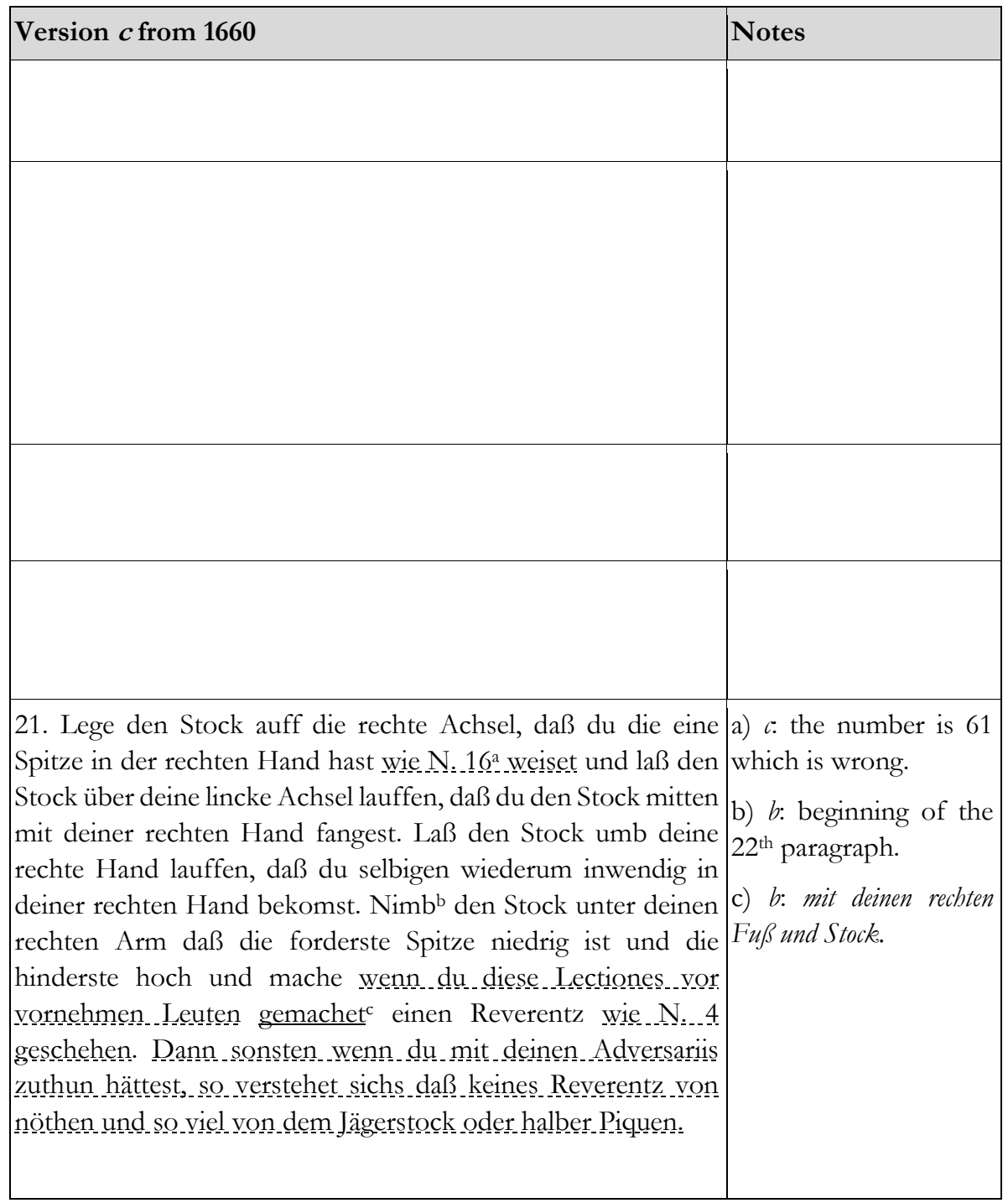




Critical edition
30. Wie die Schläge von unten herauff in alle vier Ecken
gemacht werden. Also mache selbige auch vor und hinter sich.

31. Mache die gesprungene Stockade ${ }^{\mathrm{a}}$ als mache eine Stockade und springe mit beyden Füssen fort wir N. 31 zeiget. Glißire mit der Rechten an die Lincke. Greiff mit der Lincken unter die Reche und rutsche mit der Lincken biß ans Ende und schlage hinter dich wie N. 31 b weiset. Mache eine Spaniol-stockade halb Rechts herumb wie N.32 weiset und solches mache in alle vier Ecken.

32. ${ }^{\text {a }}$ Mache diese Spanier-stockade in alle vier Ecken halb a) Only in version $e$ herumb.

33. ${ }^{a}$ Diese Lection kanstu auch vor und hinter sich machen. a) 32 in $f$ version. Wann du diese Lection aber zurück machest, so mustu mit deinen Füssen zurücke springen.

34. ${ }^{a}$ Lege den Stock auff die rechte Achsel, daß du die eine a) 33 in $f$ version. Spitze in der rechten Hand hast wie N. 33 weiset und laß den Stock über deine lincke Achsel lauffen das du den Stock mitten mit deiner rechten Hand fangest wie N. 34 zuersehn. Laß den Stock umb deine rechte Hand lauffen das du selbigen wiedrum inwendig in deiner rechten Hand bekomst. Nimb den Stock unter deinen rechten Arm das die forderste Spitze niedrig ist und die hinderste hoche und mache wann du diese Lectiones vor vornehmen Leuten exercirest einen Reverentz wie N. 5 geschehen. Dann sonsten wenn du mit deinen Adversariis zu thun hättest, so verstehet sichs das keine Reverentz von nöthen und so viel von dem Baston à deux bous, Jägerstock oder halber Piquen. 


\section{APPENDIX}

\section{IV.1. Edition of the partial version $a^{\prime}$}

The following table gives the complete text of the hunting staff part of the first publication $a$ 'in the left column. The right column gives the matching paragraph number in the ideal version.

\begin{tabular}{|c|c|}
\hline Text & Paragraph \\
\hline Jägerstock oder Partisan & title \\
\hline Der Stock wird auff dreyerley manier getragen & $\begin{array}{l}\text { beginning of } \\
\text { introduction }\end{array}$ \\
\hline Reverentz & end of introduction \\
\hline Wie man sich stellet. & beginning of $\S 1$ \\
\hline Vor und hinden glisirt in alle vier Ecken & end of $\S 1$ \\
\hline Spaniol-Stockaden in alle vier Ecken und darzu gestossen & $\S 2$ \\
\hline Spaniol-Stockaden halb herumb und dazu gestossen in alle vier Ecken & $\$ 3$ \\
\hline Spaniol-Stockaden halb rumb ohnen stossen & $\$ 4$ \\
\hline Uber den Kopf gedrehet und dazu gestossen in alle vier Ecken & $\$ 6$ \\
\hline Diese Lection halb rumb und dazu gestossen in alle vier Ecken & $\S 7$ \\
\hline Diese Lection halb rumb ohne stossen & $\S 8$ \\
\hline Paraden von oben vor und zurück & $\S 11$ \\
\hline Paraden von unten vor und zurück & $\S 12$ \\
\hline Paraden von oben rechts rund rumb & abandoned \\
\hline Paraden von unten rechts rund rumb & abandoned \\
\hline Zurück glisirt und gehauen vor und zurück & $\S 13$ \\
\hline Mit beyden Händen gehauen vor und zurück & $\S 16$ \\
\hline Auff beyden seiten gehauen vor und zurück daß der Stock allezeit an die Arme kommt & $\S 17$ \\
\hline Rund rumb gehauen rechts & $\$ 21$ \\
\hline Rund rumb gehauen links & $\S 22$ \\
\hline Zurück glisirt und nieder geschlagen zweymahl in alle vier Ecken & $\S 23$ \\
\hline Diese Lection halb rumb mit zween Schlägen & $\$ 24$ \\
\hline Diese Lection halb rumb mit einem Schlag & $\$ 25$ \\
\hline Diese Lection halb rumb mit zween Schlägen nach dem Ellebogen in alle vier Ecken & $\$ 27$ \\
\hline Diese Lection halb rumb mit zween Schlägen & $\S 28$ \\
\hline Diese Lection nach dem Ellebogen halb rumb mit einem Schlag & $\$ 29$ \\
\hline Spaniol-Stockaden mit verkehrer Hand in alle vier Ecken und darzu gestossen & abandoned \\
\hline Diese Lection halb rumb und darzu gestossen & abandoned \\
\hline Diese Lection halb rumb ohne stossen & abandoned \\
\hline Den Stock hinter gestossen und geschlagen & abandoned \\
\hline $\begin{array}{l}\text { Den Stock auff die rechte Achsel gelegt und herumb lauffen lassen daß er in } \\
\text { die rechte Hand kommt }\end{array}$ & beginning of $\S 34$ \\
\hline Den Stock umb die rechte Hand lauffen lassen & middle of $\S 34$ \\
\hline Reverentz & end of $\S 34$ \\
\hline
\end{tabular}




\section{IV.2. Collombon's text about baston à deux bouts}

This extract comes from the book of Collombon, pages 15 to 16 . It is the most detailed technical source on the French staff of the seventeenth century, though the extensive use of technical terms without any explanations makes it difficult to understand.

Le jeu du Baston à deux bout.

Le baston à deux bout se porte de deux façons sur l'épaule ou bien en contrepoids, le bras estendu en bas, lors qu'on est en crainte, faut presenter la pointe, luy envoyer une estocade, faire un faut montant pour le faire retirer, puis tourner visage, faire virer le baston, tirer deux estocades devant $\&$ dernier ${ }^{51}$ en se tournant. Puis les faux montans de deux costez, puis les passées en tournant le corps, les faire deux fois, puis le moulinet, envoyant une estocade dernier, le faire deux fois en parant, puis le point en dernier, le faire deux fois, puis le moulinet en déchargeant, le faire deux fois en changeant de main, puis le moulinet passant par devant, puis les décharges, passant dessous le baston, les faire deux fois, puis les doubler, décharger deux fois puis les largir, tourner le corps, les faire deux fois, puis s'arrester pour voir dequel costé faut aller, puis tirer les quatre pointes devant, dernier, faire comme estant en lieu estroit, \& ce qui est necessaire de faire; Car il ne faut pas chercher le commencement ny la fin, mais se servir des tours qui vous puissent servir. Voila tout le jeu du baston à deux bout.

51 The word « dernier» («last») was systematically used in this book with the meaning of « behind » or «back». 


\section{BIBLIOGRAPHY}

\section{V.1. Primary sources}

Allain Manesson Mallet, Les travaux de Mars ou l'art de la guerre, 3, Paris, Denys Thierry, 1684.

Charles Besnard, Le maistre d'arme libéral, Rennes, Julien Herbert, 1653.

Christoph Schrader, Die treue Gebülffin eines Ehemannes an der Wobl erbarn, Hoch-Ehr und Tugendreichen Frauen Annen Margarethen gebohrnen Sieglerin, des Edlen Großachtbaren und Woblgelabrten Herrn Johann Georg Paschn... Halle, Salfeld, 1678. Exemplary consulted: Berlin, state library, 710-257, 43. < http:// resolver.staatsbibliothekberlin.de/SBB0000905100000000>, accessed 15 November 2015.

Christoph Schrader, Woblanständige Exercitia Eines Christen Dem Weiland Edlen Großachtbaren und Woblgelahrten Herrn Johann Georg Paschn... Halle, Salfel, 1678. Exemplary consulted: Erfurt, University and research library Erfurt/Gotha, LP D $8^{\circ}$ III, 00007 (11).

Festivitati Nuptiali Viri Clarissimi et Consultissimi Dni. Johannis Georgii Paschn, Serenissimi, Principis Magdeb. Secretarii Digniss. Sponsi Cum Virgine Anna Margarita Sieglerin, bonis omnibus prosequuntur Fautores et Amici Wittebergernses, Wittenberg, Hake, 1657.

Exemplary consulted: Halle, University and Federal Library from Sachsen-Anhalt, an Pon Zd 198 (4). <http://nbn-resolving.de/urn:nbn:de:gbv:3:1-89363>, accessed 15 November 2015.

Jacques Collombon, Traité de l'exercice militaire, où est l'instruction des jeux de toutes sortes d'armes, et celuy du drapeau, avec une méthode très facile pour faire faire l'exercice aux soldats et dresser toutes sortes de bataillons, Lyon, Pierre Anard, 1650.

Johann Georg Pasch, Anleitung sich bei grossen Herrn, Höfen und andern beliebt zu machen, ed. by Uwe W. Schlottermüller (Freiburg: fa-gisis, 2000).

Johann Georg Pasch, Deutliche Beschreibung unterschiedener Fabnen-Lectionen in acht Spiel eingetheilet, nebst dem Piquen-Spiel, Pertuisan und halben Piquen, oder Jägerstock, Halle, Melchior Ölschlegel, 1673. Exemplary consulted: Wolfenbüttel : Herzog August Bibliothek, Xb $4^{\circ}$ 157. <http://diglib.hab.de/drucke/xb-4f-157/start.htm>, accessed 29 January 2016.

Johann Georg Pasch, Deutliche Beschreibung von dem Exerciren in der Musquet und Pique, wie auch von dem Baston a deux Bous, Jägerstock, Halle, Christian Vester, 1667. Exemplary consulted: Forschungsbibliothek Gotha, Math $2^{\circ}$ 00326/01 (01) < http://nbnresolving.de/urn/resolver.pl?urn=urn:nbn:de:urmel-99313174-0a07-4f3c-848706d9b0ff51671>, accessed 15 November 2015.

Johann Georg Pasch, Dissertatio De Plagio Kaufungiano Anno MCCCCLV. Commisso... Wittenberg, Johann Röhner, 1655. Exemplary consulted: Dresden, State Library, Hist.Sax.C.623,19 <http://nbn-resolving.de/urn:nbn:de:gbv:3:1-17851>, accessed 15 November 2015. 
Johann Georg Pasch Dissertatio Politica de Legato / Quam praeside Dn. Michaele Wendelero ... Johannes Georgius Pascha, Dresd. A. \& R. in Auditorio Majori, die XVII. Martii, Wittenberg, Johann Röhner, 1652.

Johann Georg Pasch, Kurtze Anleitung Wie der Jägerstock oder halbe Pique eigentlich zugebrauchen und was vor Lectiones darauff seyn, Halle, Melchior Ölschlegel, 1660. Exemplary consulted: Göttingen, Niedersaechsische Staats- und Universitätsbibliothek, 8 ARS MIL 1106/3 (3). <http://resolver.sub.unigoettingen.de/purl?PPN591440717>, accessed 14 December 2015.

Johann Georg Pasch, Kurtze Anlejdung wie der Baston à deux bous das ist Jaegerstock, balbe Pique oder Springe-Stock eigentlich zu gebrauchen, Leipzig, Friedrich Arnst, 1670. Exemplary consulted: Wolfenbüttel : Herzog August Bibliothek, H: N 223.2 Helmst. < http://nbn-resolving.de/urn:nbn:de:gbv:23-drucke/n-223-2f-helmst6>, accessed 10 March 2016.

Johann Georg Pasch, Kurtze doch Gründliche Unterrichtung der Pique, deß Trillens in der Pique, der Fabne, deß Jägerstocks, Trincierens, Fechtens auf den Stoß und auf den Hieb, Voltesirens auf den Pferd und auf den Tisch, deß Ringens, Tantzens, Osnabrück, Johann Georg Schwander, 1659. Exemplary consulted: Stuttgart, Federal Library, Sport.oct.357. <http://digital.wlb-stuttgart.de/purl/bsz371927072>, accessed 15 November 2015.

Johann Georg Pasch, Kurtze jedoch Deutliche Beschreibung handlend von Fechten auß dem Stoss und Hieb, Halle, Melchior Ölschlegel, 1661. Exemplary consulted: Stuttgart, Federal Library, MC Sport.qt.52.

Johann Georg Pasch, Kurtze Unterrichtung Belangend Die Pique, die Fabne, den Jägerstock, das Voltegiren, das Ringen, das Fechten auff den Stoß und Hieb und endlich das Trinciren, Wittenberg, Ölschlegel, 1657 (ré-ed. 1658, 1659). Exemplary consulted: Wolfenbüttel, Herzog-August-Bibliothek, Hn $198<$ http://nbnresolving.de/urn:nbn:de:gbv:23-drucke/hn-1988>, accessed 15 November 2015.

Johann Georg Pasch, Vier und achtzig Fabnen-Lectiones, Halle, Melchior Ölschlegel, 1661. Exemplary consulted: Göttingen, Niedersaechsische Staats- und Universitätsbibliothek, 8 ARS MIL 908/15. < http://resolver.sub.unigoettingen.de/purl?PPN59394447X>, accessed 14 December 2015.

Johann Georg Pasch, Vollständiges Fecht-Ringe und Voltigier Buch, Halle, Christian Vester, 1666. Exemplary consulted: Vienna, Austrian National Library, 72.C.38. <http://data.onb.ac.at/ABO/\%2BZ184136601>, accessed 08 December 2015.

L'État de la France où l'on voit tous les Princes, Ducs et Pairs, Marêchaux de France, et autres Officiers de la Courone... Paris, A. Besongne, 1677.

Louis de Gaya, Traité des armes, des machines de guerre, des feux d'artifice, des enseignes et des instrumens militaires, Paris, Sébastien Cramoisy, 1678.

Nathanael Duez, Le vray et parfait guidon de la langue francoise, Amsterdam, Ludwig and Daniel Elzevier, 1662.

Pierre Giffart, L'Art militaire francois pour l'infanterie contenant l'exercice et le maniement des armes, tant des officiers que des soldats, Paris, Pierre Giffart, 1696. 


\section{V.2. Secondary sources}

Anglo, Sydney, L'escrime, la danse et l'art de la guerre, le livre et la représentation du mouvement (Paris: Bibliothèque nationale de France, 2011).

Anglo Sydney, Martial Arts of Renaissance Europe (New Haven: Yale University Press, 2000).

Bibza, Gábor, Die deutschsprachige Leichenpredigt der frühen Neuzeit in Ungarn (1571 - 1711) (Berlin: Lit Verlag, 2010).

Brulliot, François, Dictionnaire des monogrammes, marques figurées, lettres initiales, noms abrégés, etc., 3 vols. (Munich: J.G. Cotta, 1832-34).

Brunt, Richard J., The Influence of the French Language on the German Vocabulary (1649-1735), Studia Linguistica Germanica 18 (Berlin, New York: De Gruyter, 1983).

Crawley, T. Philip, The Polearm Compendium <http://www.lulu.com/shop/philip-tcrawley/the-polearm-compendium/ebook/product-20700660.html $>$, accessed 15 November 2015.

Der Altenburger Prinzenraub 1455: Strukturen und Mentalitäten eines spätmittelalterlichen Konflikts, ed. by Joachim Emig (Beucha: Sax-Verlag, 2007).

Dupuis, Olivier, 'L'escrime au bâton et à la canne en France, du XVIe au XIXe siècle', Arts de combat, Théorie \& pratique en Europe - XIVe-XXe siècle, ed. by Fabrice Cognot (Dijon: AEDEH, 2011), pp. 153-82.

Dupuis, Olivier. 'Organization and Regulation of Fencing in the Realm of France in the Renaissance’, Acta Periodica Duellatorum, 2 (2014), 233-54.

Gabler, Hans Walter, 'Textual Criticism and Theory in Modern German Editing', Contemporary German Editorial Theory, ed. by Hans Walter Gabler, George Bornstein and Gillian Borland Pierce (Ann Arbor: The University of Michigan Press, 1995), pp. 1-16.

Guntau, Martin, 'Die frühen norddeutschen Universitätsgründungen Rostock und Greifswald', Ein Jahrtausend Mecklenburg und Vorpommern : Biographie einer norddeutschen Region in Einzeldarstellungen, ed. by Wolf Karge (Rostock: Hinstorff, 1995), pp. 97-102.

Hazebroucq, Hubert, La technique de la danse de bal vers 1660 : nowvelles perspectives, master 2 dissertation (University of Reims 2013), <http://dumas.ccsd.cnrs.fr/dumas$00994362>$, accessed 15 November 2015.

Jones, William Jervis, A Lexicon of French Borrowings in the German Vocabulary (1575-1648), (Berlin, New York: De Gruyter, 1976).

Kathe, Heinz, Die Wittenberger Philosophische Fakultät 1502 - 1817 (Köln, Weimar, Wien: Böhlau, 2002).

Köbler Gerhard, Historisches Lexikon der Deutschen Länder: die deutschen Territorien vom Mittelalter bis zur Gegenwart (Munich: Beck, 2007).

Krebs, Jean-Daniel, 'Quand les allemands apprenaient à trancher', Études Germaniques, 41 (1986), 8-23. 
Lahaye, Matthieu, Le fils de Lonis XIV : monseigneur le Grand Dauphin, 1661-1711 (Seyssel : Champ vallon, 2013).

Müller, Georg, 'Ein Versuch zur Gründung einer Ritterakademie zu Dresden (1674)', Neues Archiv für Sächsische Geschichte und Altertumskunde, 10 (1889), 43-57.

Murdoch, Steve and Grosjean, Alexia, Alexander Leslie and the Scottish Generals of the Thirty Years' War, 1618-1648 (London: Pickering \& Chatto, 2014).

Scholz, Günter and Vogelsang, Klaus, Einheiten, Formelzeichen, Größen (Leipzig: Fachbuchverlag, 1991).

Sikora, Michael, 'Die Mechanisierung des Kriegers', Bewegtes Leben, Körpertechniken in der Früben Neuzeit, ed. by Rebekka von Mallinckrodt (Wiesbaden: Harrassowitz, 2008), pp. 143-166.

Van Noort, Reinier, Pascha's Hunting Staff, $<$ http://www.bruchius.com/docs/Pascha $\% 20$ Hunting $\% 20$ Staff $\% 20$ by $\% 20$ RvN.pdf $>$, accessed 8 March 2016.

Van Noort, Reinier, Pascha's Staff with Two Ends, $<$ http://www.bruchius.com/docs/Pascha $\% 20$ Hunting $\% 20$ Staff $\% 20$ by $\% 20$ RvN.pdf $>$, accessed 8 March 2016.

Wehrmann, Martin, 'Geschichte des Königlichen Marienstifts-Gymnasiums 1544-1894', Festschrift zum dreibunderffünfrigä̈hrigen Jubiläum des Königlichen Marienstifts-Gymnasiums ₹ฺ Stettin am 24 und 25 September 1894 (Herrcke \& Lebeling: Stettin 1894). pp. 1-164.

Wellmann, Janina, 'Hand und Leib, Arbeiten und Üben. Instruktionsgraphiken der Bewegung im 17. und 18. Jahrhunder', in Bewegtes Leben Körpertechniken in der frühen Neuzeit, ed. by Rebekka von Mallinckrodt (Wiesbaden: Harrassowitz, 2008), pp. 1538.

Wellmann, Janina, 'Katalog, Hand und Leib, Arbeiten und Üben', in Bewegtes Leben Körpertechniken in der frühen Neuzeit, ed. by Rebekka von Mallinckrodt (Wiesbaden: Harrassowitz, 2008), pp. 249-59. 